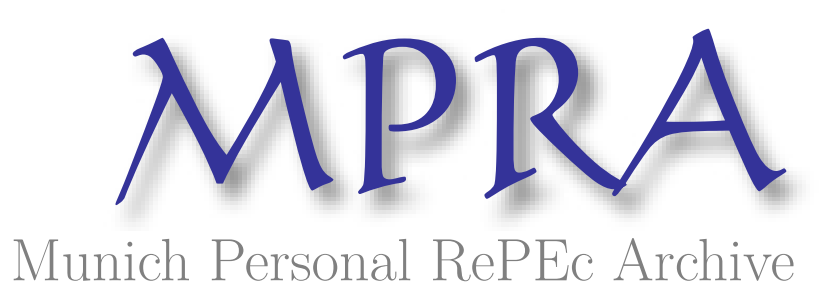

\title{
Billionaires, millionaires, inequality, and happiness
}

Popov, Vladimir

21 May 2019

Online at https://mpra.ub.uni-muenchen.de/94081/

MPRA Paper No. 94081, posted 28 May 2019 17:16 UTC 


\title{
Billionaires, millionaires, inequality, and happiness ${ }^{1}$
}

\section{Vladimir Popov ${ }^{2}$}

\begin{abstract}
The relationship between inequality and happiness is counterintuitive. This applies to both inequality in income and wealth distribution overall and also inequality at the very top of the wealth pyramid, as measured by billionaire intensity (the ratio of billionaire wealth to GDP). First, billionaire intensity appears to be higher in countries with low, not high, levels of income inequality. Second, happiness indices are higher in countries with high percentages of billionaire and millionaire wealth as a proportion of GDP, but with low levels of income inequality.
\end{abstract}

This paper uses databases from the Forbes billionaires list, the Global Wealth Report (GWR), and the World Happiness Report, as well as from the World Database on Happiness. Using these datasets, I examine the relationship between income inequality and happiness for over 200 countries from 2000 to 2018.

It turns out that in relatively poor countries - below $\$ 20,000-\$ 30,000$ per capita income inequality raises happiness rather than lowers it, but inequality has a negative impact on happiness in rich countries. A certain degree of inequality of wealth and income distribution has a positive impact on happiness feelings, especially in countries with low levels of income. Furthermore, wealth inequalities, and especially the degree of concentration of wealth at the very top of the wealth pyramid, raise happiness self-evaluations even when income inequalities lower it.

Keywords: inequality in income and wealth distribution, share of billionaires' and millionaires' wealth in GDP, happiness indices

\section{JEL: D31, D63, I31}

\footnotetext{
${ }^{1}$ This paper is the logical continuation of my two 2018 papers 'Paradoxes of happiness. Why do people feel more comfortable with high levels of inequality and high murder rates?' DOC Expert Comment, 18 June 2018 and 'Why do some countries have more billionaires than others? Explaining variations in the billionaire-intensity of GDP'. DOC Expert Comment, 24 July 2018.

${ }^{2}$ Dialogue of Civilizations Research Institute, Berlin, Germany. My thanks go to Tony Shorrocks who kindly provided me with the excel table of the GWR database. I am also most grateful to Elena Sulimova for collecting the data and preparing the database for the analysis.
} 


\section{Billionaires, millionaires, inequality, and happiness ${ }^{3}$}

\section{Vladimir Popov ${ }^{4}$}

\section{Literature review, puzzles, and hypotheses}

There are some important paradoxes in the dynamics of happiness indices and the relative levels of these indices for various countries and different populations groups. One puzzle, the Easterlin paradox, is the non-increasing level of happiness in the US in spite of constantly rising personal incomes (fig. 1). ${ }^{5}$

Figure 1: Average happiness score (left scale) and GDP per capita, dollars, (right scale) in the US in 1972- 2016

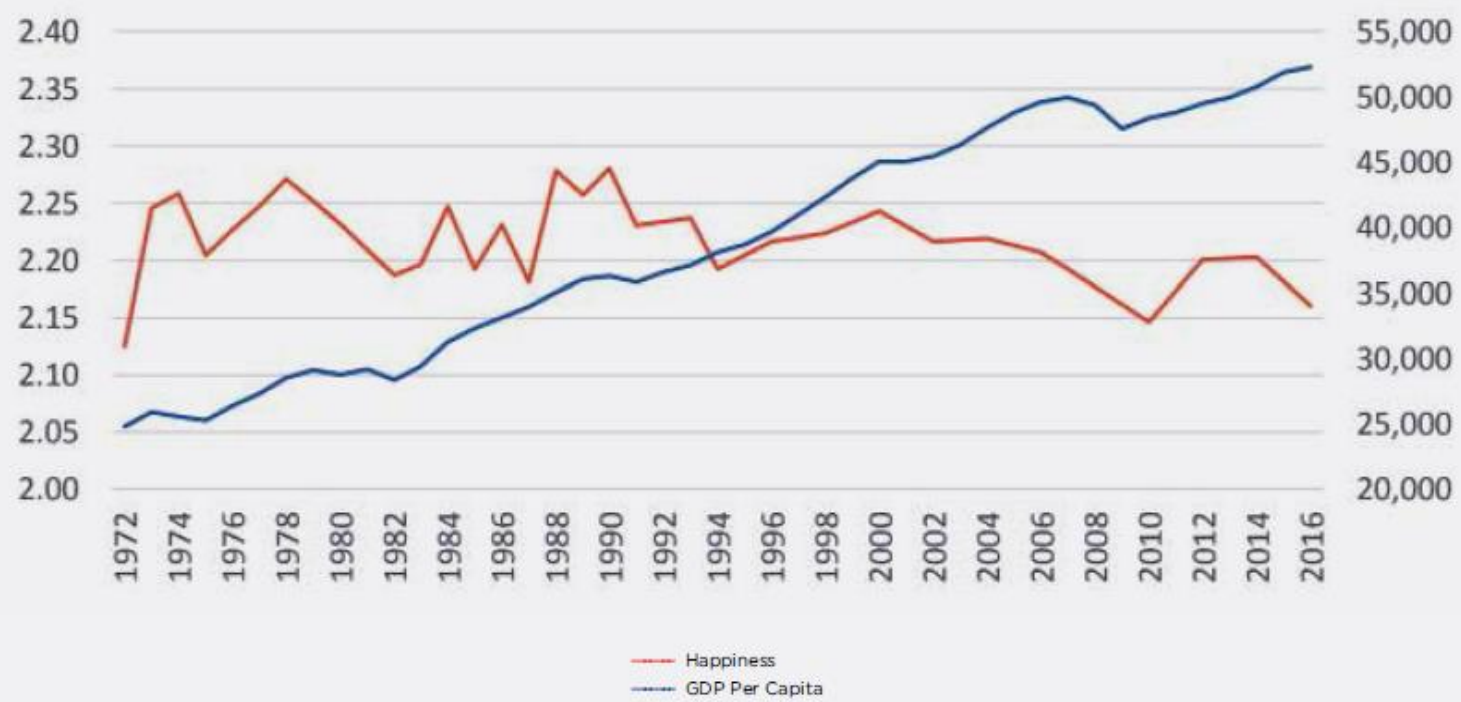

Source: Sachs (2018).

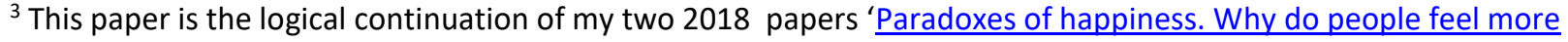
comfortable with high levels of inequality and high murder rates?' DOC Expert Comment, 18 June 2018 and 'Why do some countries have more billionaires than others? Explaining variations in the billionaire-intensity of GDP'. DOC Expert Comment, 24 July 2018.

${ }^{4}$ Dialogue of Civilizations Research Institute, Berlin, Germany. My thanks go to Tony Shorrocks who kindly provided me with the excel table of the GWR database. I am also most grateful to Elena Sulimova for collecting the data and preparing the database for the analysis and to Jonathan Grayson for editing.

${ }^{5}$ The happiness index in this paper is taken from the World Database on Happiness. This is a self-evaluation of personal happiness on a scale from 0 to 10 , derived from surveys.
} 
Sachs (2018) argues that America's subjective wellbeing is being systematically undermined by three interrelated epidemics, notably obesity, substance abuse (especially opioid addiction), and depression. But in other countries without as much obesity, drugs, and depression, there is also a decline in happiness that goes hand in hand with rising real incomes.

In India, the happiness index score fell from 5 to 4 over the 2006-18 period despite strong growth of income in this period. In China, over the 1990-2000 decade, happiness plummeted despite massive improvements in material living standards. Brockmann, Delhey, Welzel, and Hao (2008) explain this by growing income inequality within China, i.e., in relation to the average national income, the financial position of most Chinese people deteriorated.

Similarly, in the US the recent increase in income inequalities could be responsible for the decline in happiness: in 1980-2014, the post-tax incomes of the richest $10 \%$ rose by $113 \%$; of the top $1 \%$, by $194 \%$; and of the top $0.001 \%$, by $617 \%$ (Piketty, Saez, Zucman, 2016), whereas the US happiness index score over this period fell. However, the relationship between inequality and happiness is also not straightforward and presents another puzzle.

Normally we assume that greater equality - 'inclusive development that leaves no one behind' is both morally just and desirable for the creation of happy societies. But there is evidence that income and wealth inequalities are positively associated with happiness, as measured by the happiness index, at least for a group of countries. There are some poorer countries with high income inequalities - Bolivia, Honduras, Colombia, Ecuador, Costa Rica and some other Latin American countries - and yet also with very high happiness index scores (fig. 2). It may well be that a certain degree of inequality is necessary to keep alive a kind of 'American dream': a futureoriented belief in getting rich and achieving success in life.

Alesina, Di Tella, and MacCulloch (2001) showed that there is a large, negative, and significant effect of inequality on happiness in Europe, but not in the US. It is also clear that people have different perceptions of 'correct', 'optimal', or 'just/fair' degrees of inequality. Alesina and La Ferrara (2001) found that individual support for redistribution is negatively affected by social 
mobility. People who believe that American society offers equal opportunities to all are more averse to redistribution in the face of increased mobility.

On the other hand, those who see the social rat race as a biased process do not see social mobility as an alternative to redistributive policies. Alesina and Giuliano (2009) presented evidence that individuals who believe other people try to take advantage of them rather than being fair have a strong desire for redistribution; similarly, believing that luck is more important than work as a driver of success is strongly associated with a taste for redistribution.

Inequality at the very top does not seem to lead to pressure for redistribution. In Victorian England, inequality within the elite was associated with more conditionality and less generous welfare expenditure. Removing institutional advantages that benefited the elite did not appear to reduce the effect of elite inequality, which suggests results cannot be explained by a classic median voter model (Chapman, 2018). ${ }^{6}$ Therefore, an increase in inequality at the very top may be selfperpetuating; there is no pressure to redistribute and no mechanism to automatically 'correct' the inequality.

\footnotetext{
${ }^{6}$ This model predicts that in a majority-rule voting system, the outcome selected at the polls will be the one preferred by the median voter, i.e., the voter separating one half of the electorate from the other half, if all voters are ranked according to their preferences.
} 
Figure 2: Happiness index (Word Happiness Report and World Database on Happiness), 0to-10 scale; and GINI coefficient of income inequality in percentage terms, 2000-18

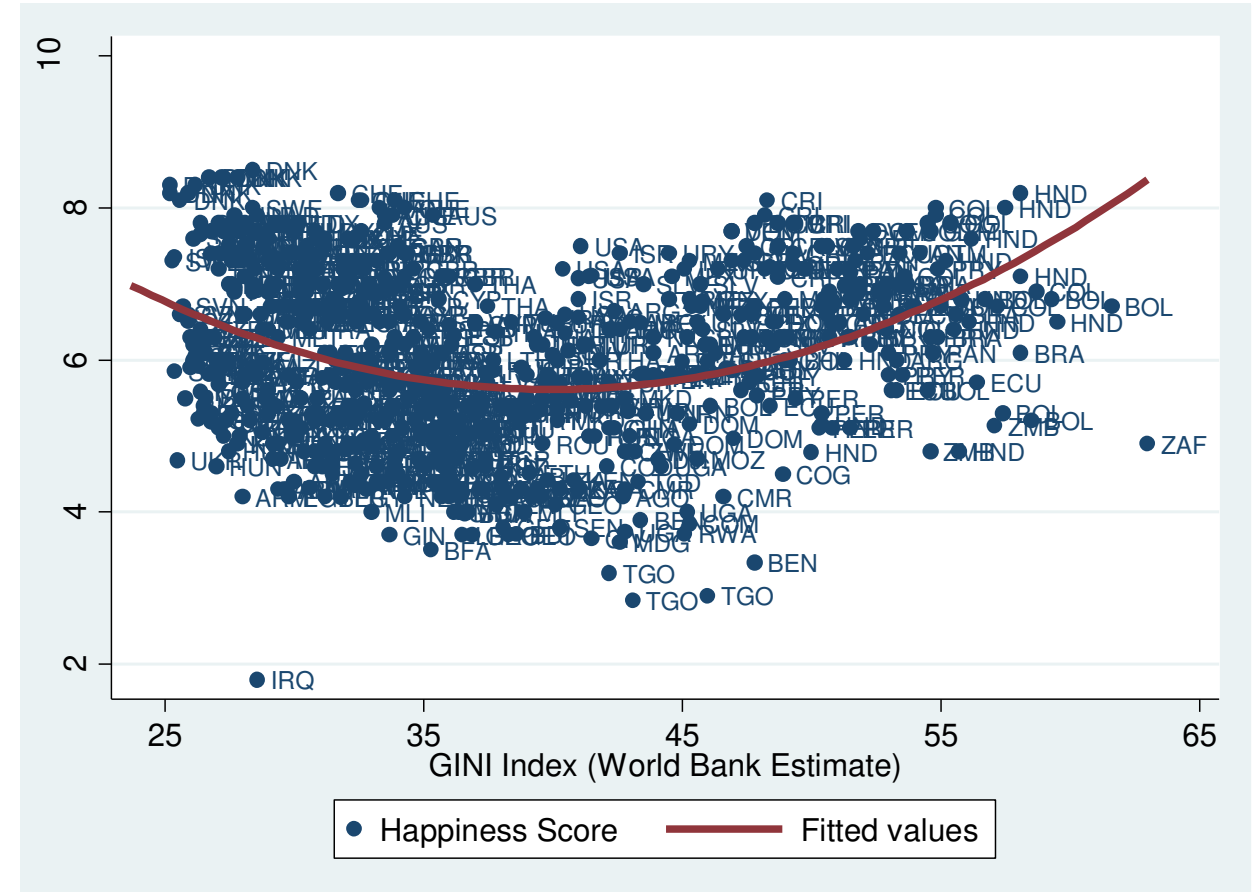

Source: World Database on Happiness (2019); WDI.

There is also some evidence that happiness is positively correlated with murder rates, especially when this goes hand in hand with inequalities (Popov, 2018a; 2018b). Inequalities lead to higher murder rates, but this does not lead to a decline in happiness, at least up to a certain point. Furthermore, happiness scores also seem almost independent of suicide rates, which is often considered an objective indicators of happiness, in contrast to happiness indices that measure selfperception through surveys where people measure their own happiness on a 0 -to-10 scale.

The relationship between self-reported happiness and objective indicators of frustration and distress is somewhat counterintuitive. Murder rates are correlated positively with happiness index scores (fig. 3), although this correlation is not statistically significant, whereas the correlation between suicide rates and happiness is negative (fig. 4), as one would expect but very weak: in regressions of happiness on murder rates, suicides rates, and per capita income, $\mathrm{R}^{2}$ is less than $2 \%$ and the suicide rate is significant only in random effects specification - it is apparent with the 
naked eye from a comparison of figure 4, which presents cross-section data for the single year of 2018, and figure 5, which presents panel data for the years 2000-18. ${ }^{7}$

The murder rate is clearly positively correlated with income inequality (fig. 6), but the suicide rate is correlated negatively, if at all (fig. 7).

Figure 3: Happiness index (Word Happiness Report and World Database on Happiness), 0to-10 scale; and murder rate per 100,000 inhabitants in 2000-18

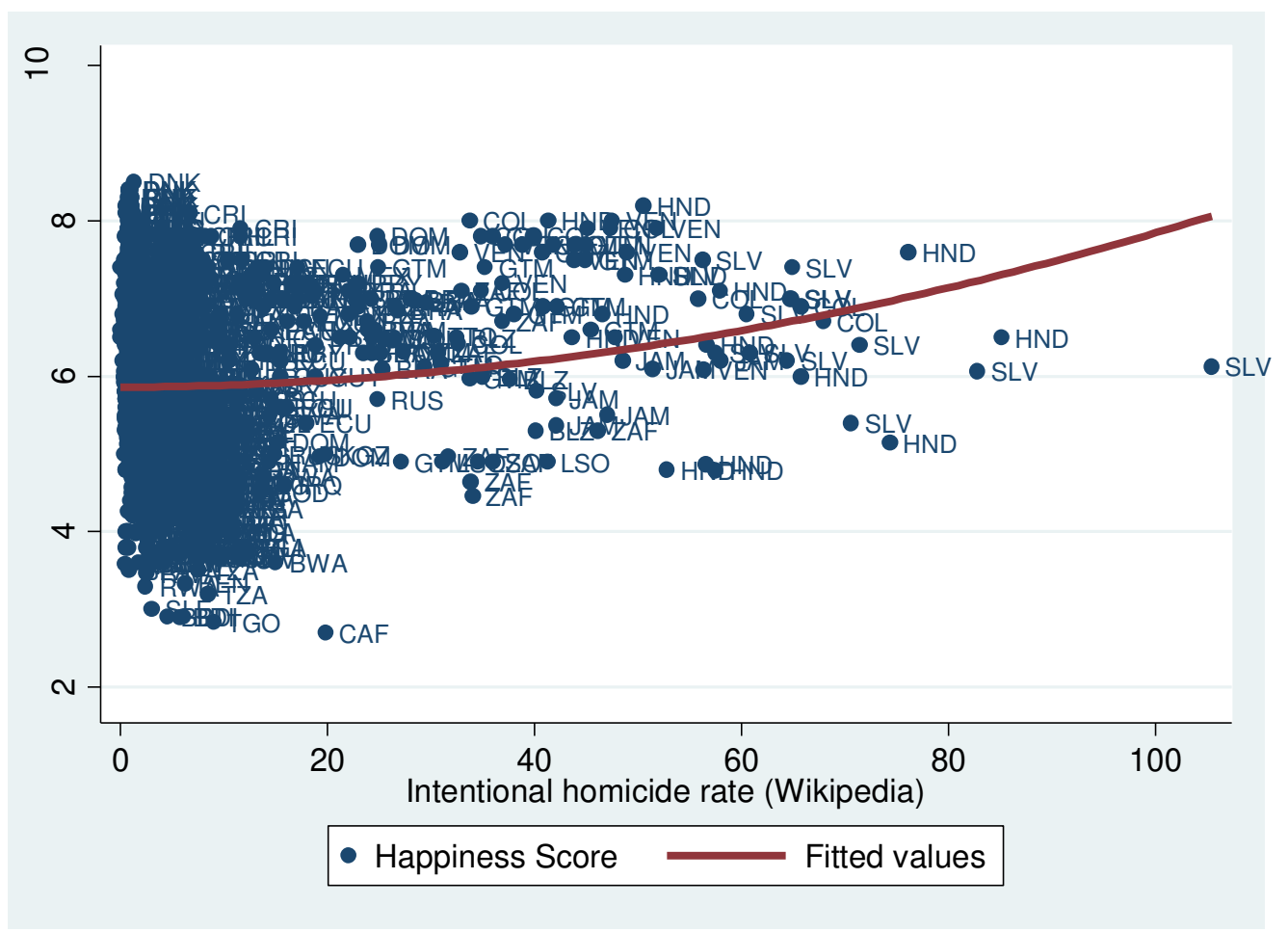

Source: WHO; World Database on Happiness.

${ }^{7}$ HappinessIndex $=5.8^{* * *}-9.7 \mathrm{e}^{-07}$ Ycap +0.007 MURDERrate $*-0.01$ SUICIDErate

$\mathrm{N}=323$ (Panel data for 2000-18 for over 200 countries, some observations are missing), $\mathrm{R}^{2}=0.014$, robust estimates, no control for fixed and random effects

HappinessIndex $=5.7^{* * *}+0.005$ MURDERrate -0.02 SUICIDErate $*$

Random effects regression, $\mathrm{R}^{2}$ (between) $=0.02, \mathrm{~N}=328$.

HappinessIndex $=5.7 * * *-1.4 \mathrm{e}^{-08}$ Ycap +0.005 MURDERrate -0.03 SUICIDErate $* *$

Random effects regression, $\mathrm{R}^{2}$ (between) $=0.02, \mathrm{~N}=323$.

Here and later the following notations are used: *,**,***-denotes significance at 10, 5 and $1 \%$ level respectively. 
Figure 4: Happiness index in 2018 and suicide rates in 2016

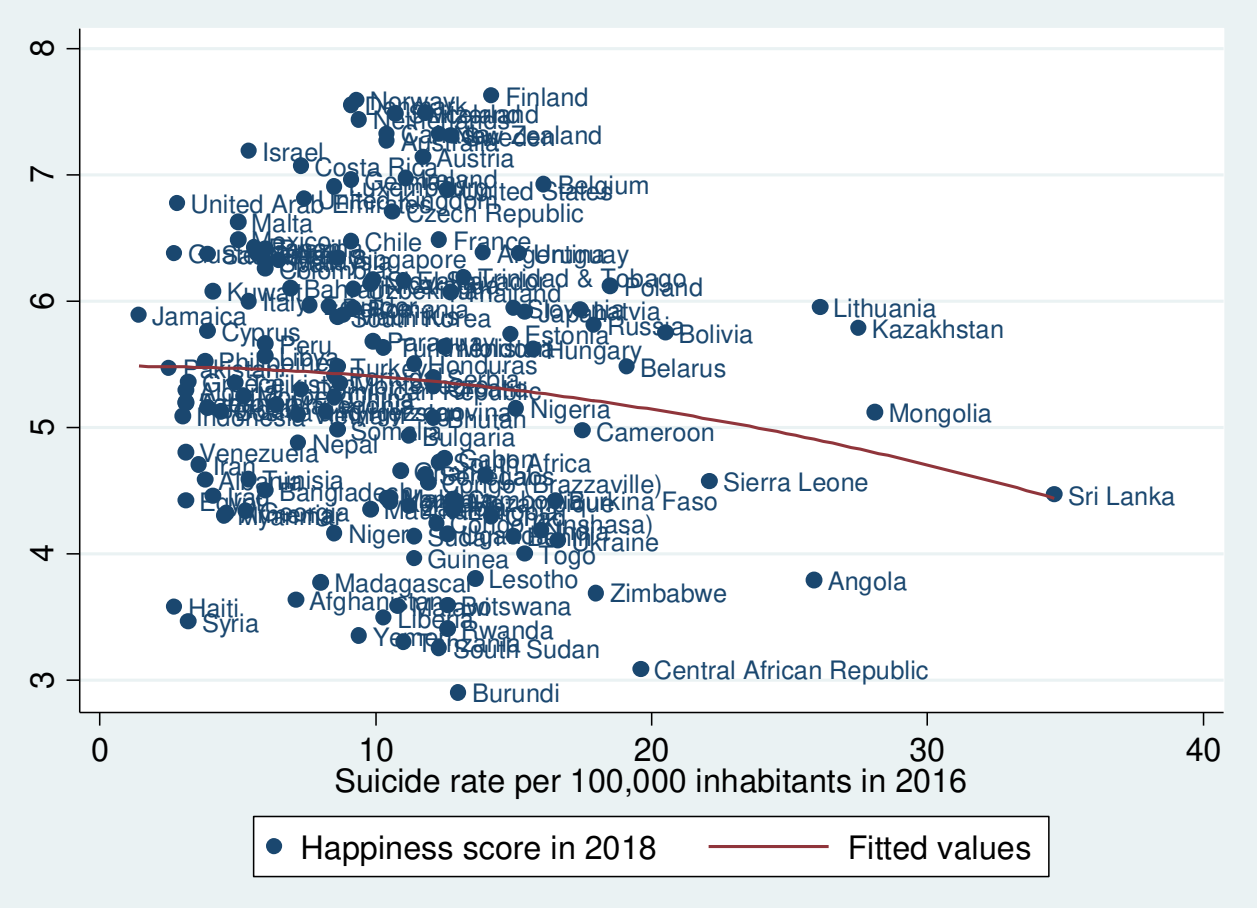

Figure 5: Happiness index and suicide rates in 2000-18

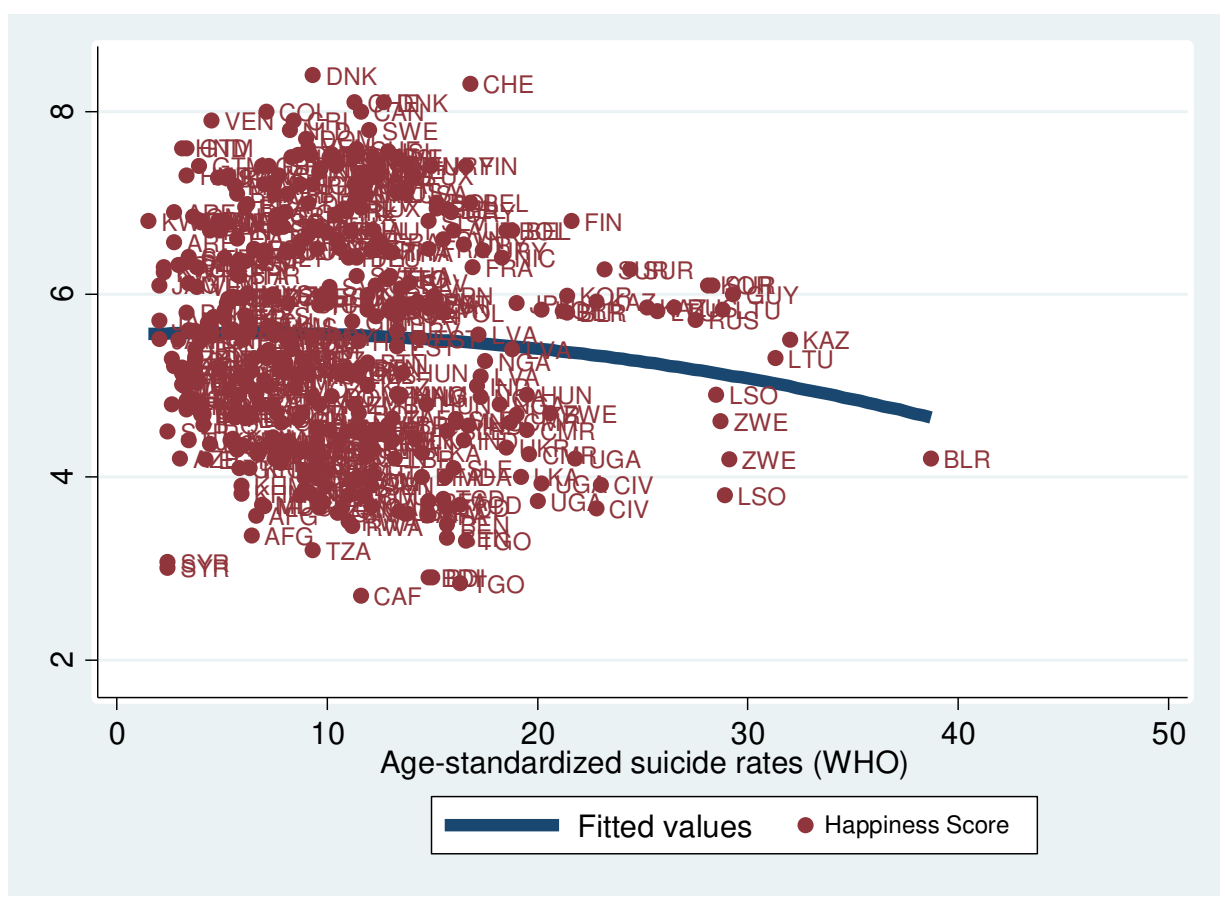

Source: WHO; World Happiness Database. 
Figure 6: Murder rate per 100,000 inhabitants and Gini coefficient of income distribution in percentage terms in $2000-18$

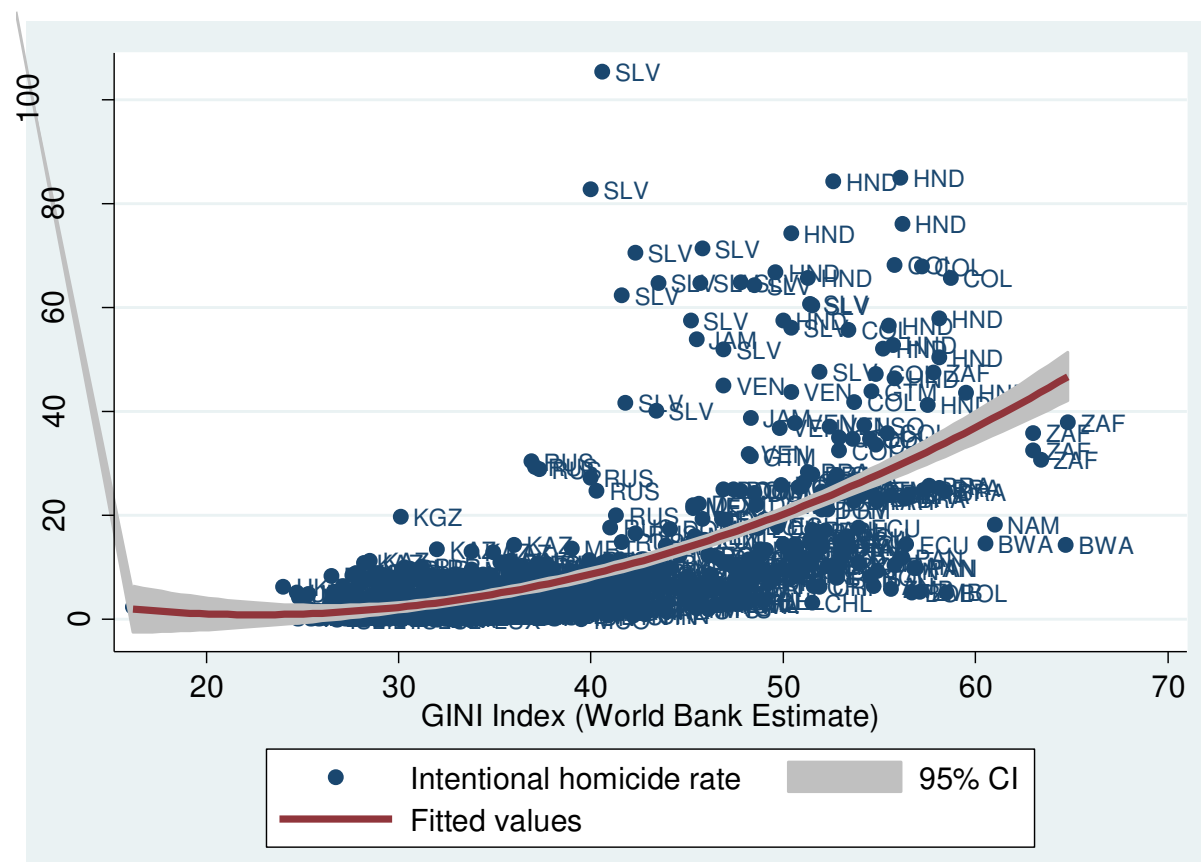

Figure 7: Suicide rate per 100,000 inhabitants and GINI coefficient of income inequality in percentage terms in $2000-18$

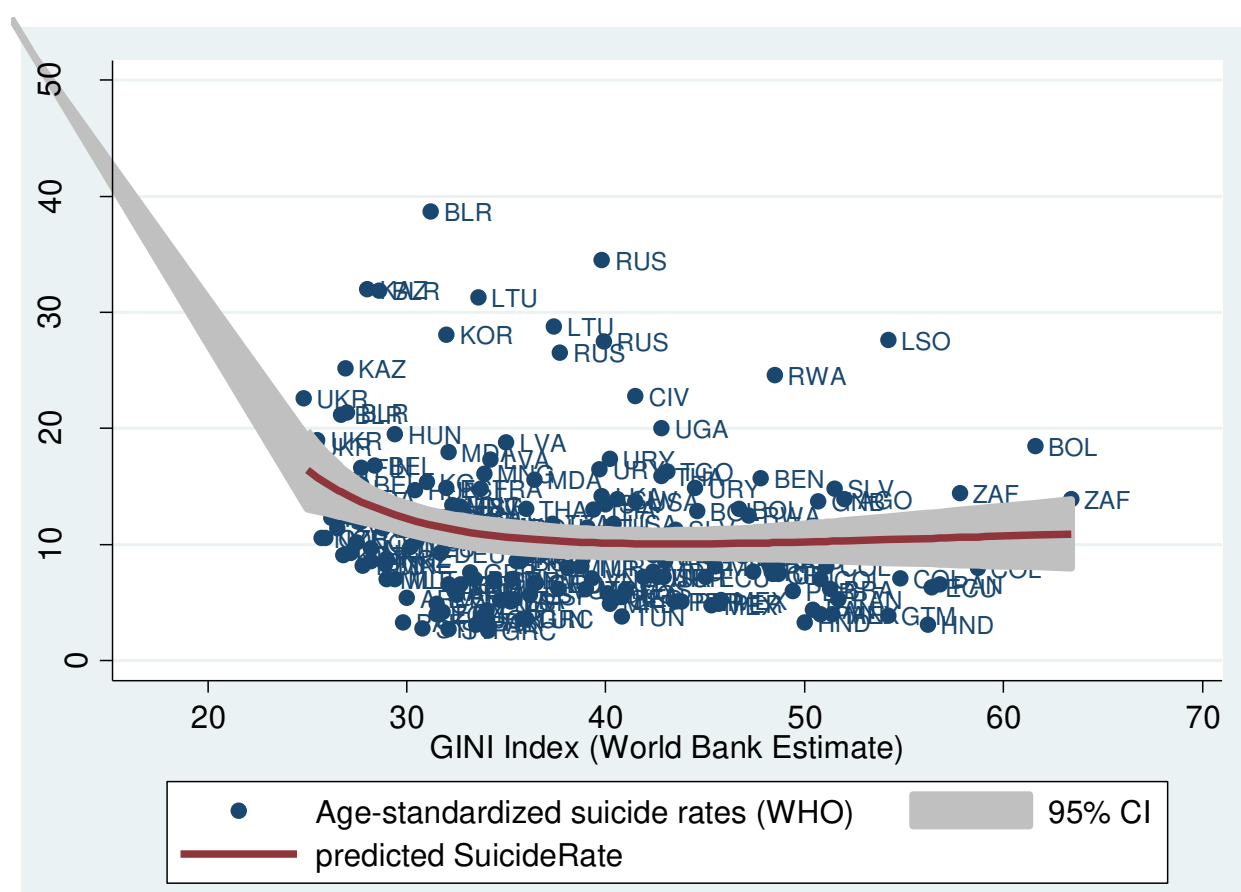

Source: WHO, WDI. 
Wealth inequalities, especially inequalities at the very top of the wealth pyramid - the share of wealth belonging to billionaires and millionaires - are positively correlated with happiness indices (fig. 8-10).

It is important to note that inequalities at the very top - billionaire and millionaire 'intensity', the ratio of billionaire/millionaire wealth to GDP - are not precisely correlated with general measures of inequalities like Gini coefficients. Whereas Gini coefficients for wealth and income distribution are positively correlated with one another (fig. 12), and billionaire intensity is positively correlated with Gini coefficients for wealth distribution (fig.13), the correlation of billionaire intensity with general income-distribution Gini coefficients is negative, if present at all (fig. 14). That is to say, there are countries with quite an even distribution of income, but levels of high billionaire intensity in GDP; e.g., Scandinavian countries.

Figure 8: Happiness index (0-to-10 scale) and billionaire wealth from the Global Wealth Report as a percentage of PPP GDP in 2018

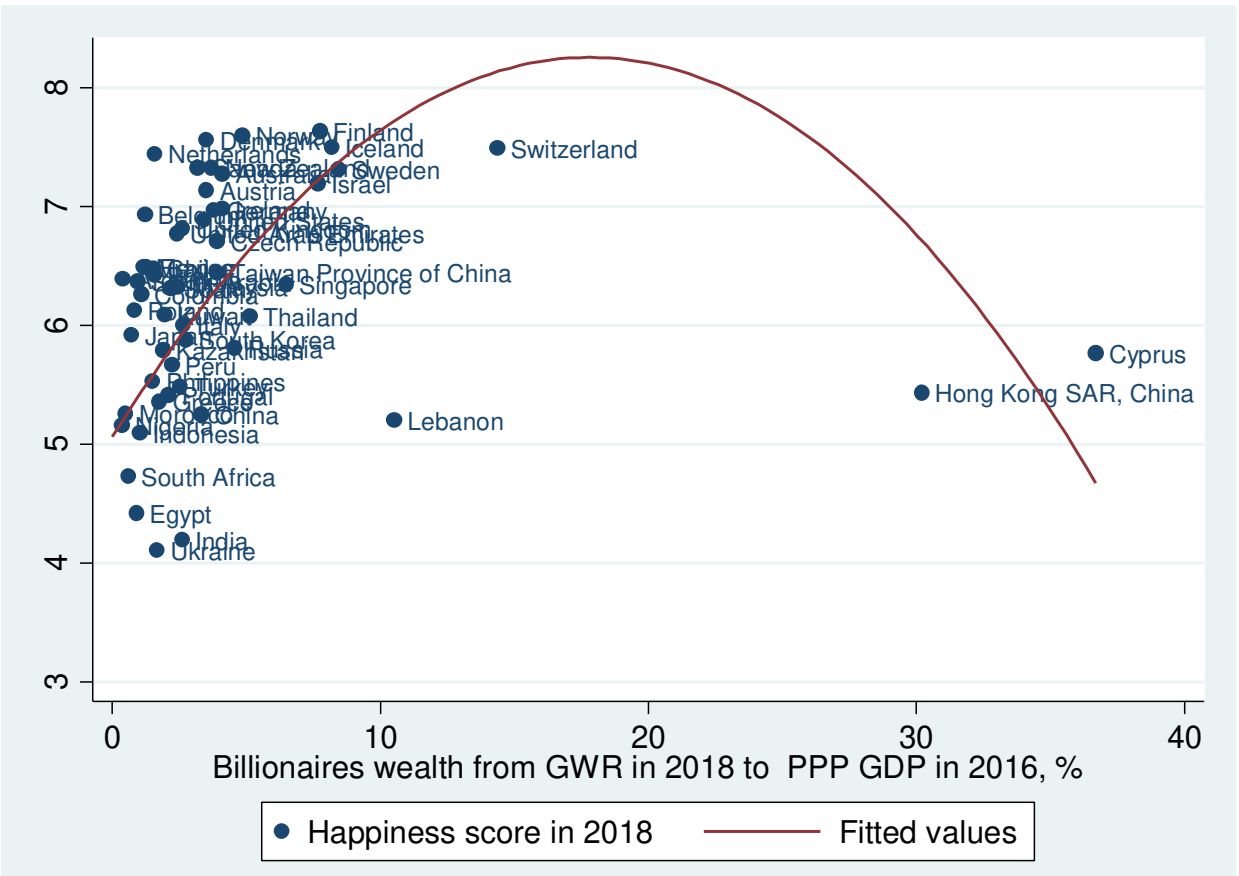


Figure 9: Happiness index (0-to-10 scale) and billionaire wealth from the Forbes list as a percentage of PPP GDP in 2018

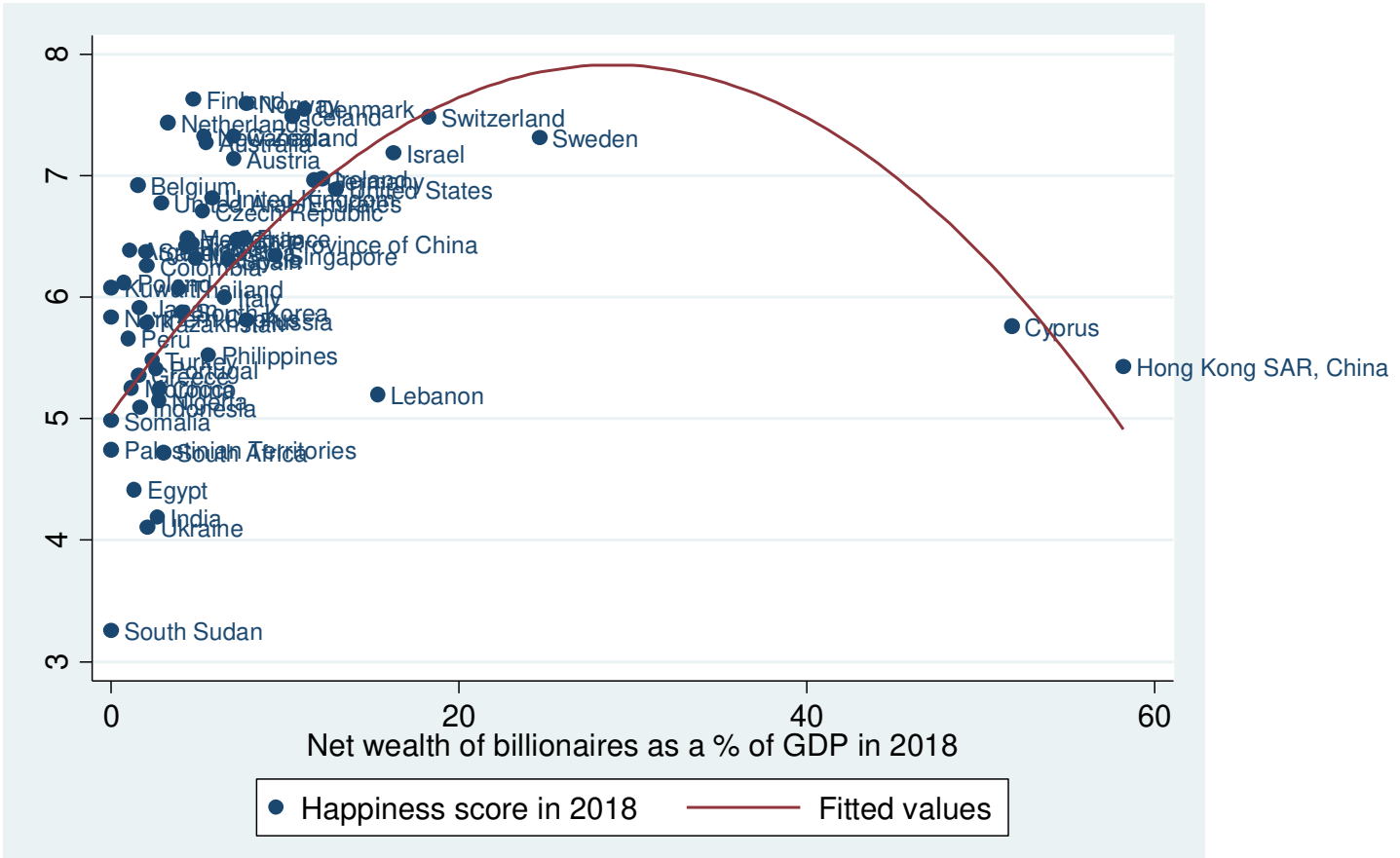

Figure 10: Happiness index (on a scale of 0 to 10) and net worth of millionaires according to the Global Wealth Report as a percentage of PPP GDP

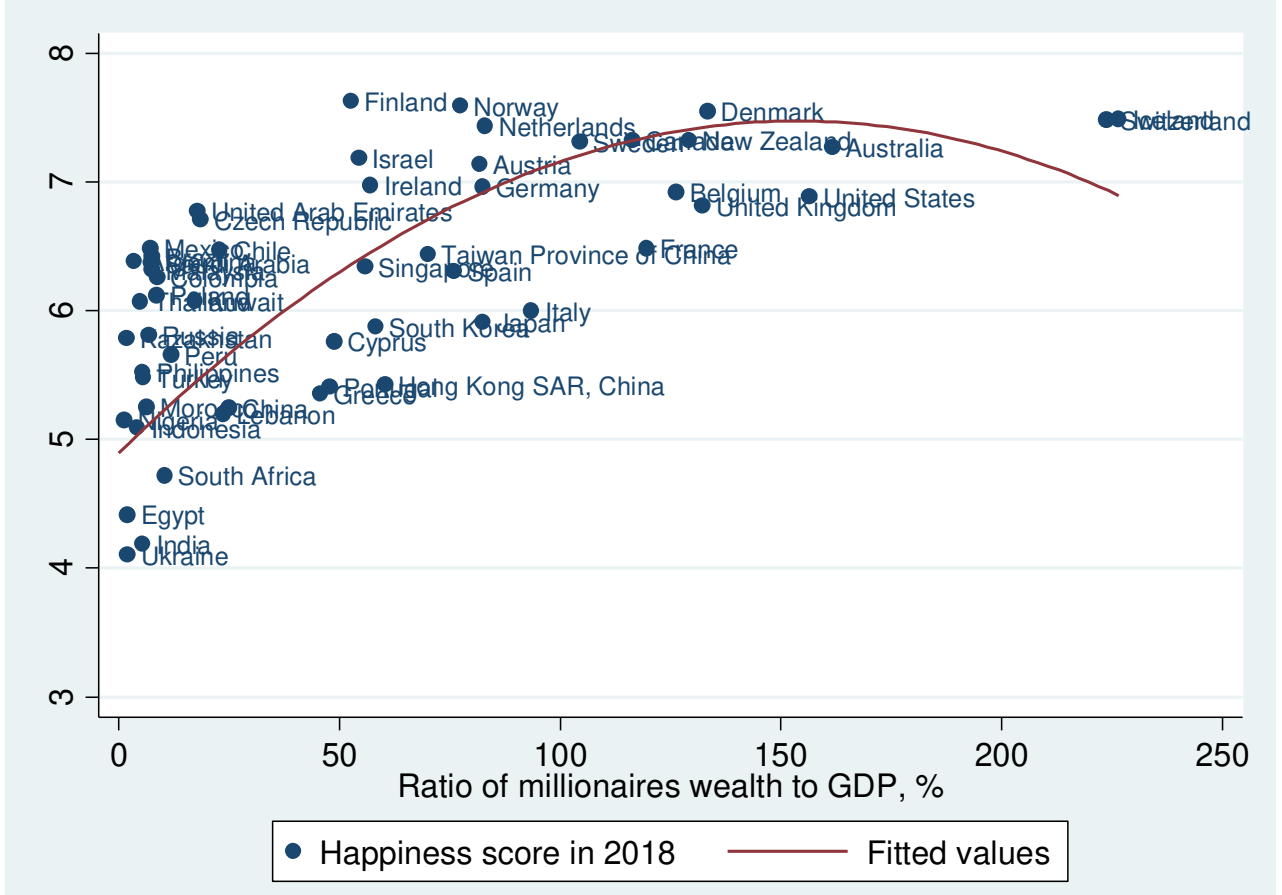


Figure 11: Happiness index (on a scale of 0 to 10) and Gini coefficient of wealth distribution in 2018, percentage terms

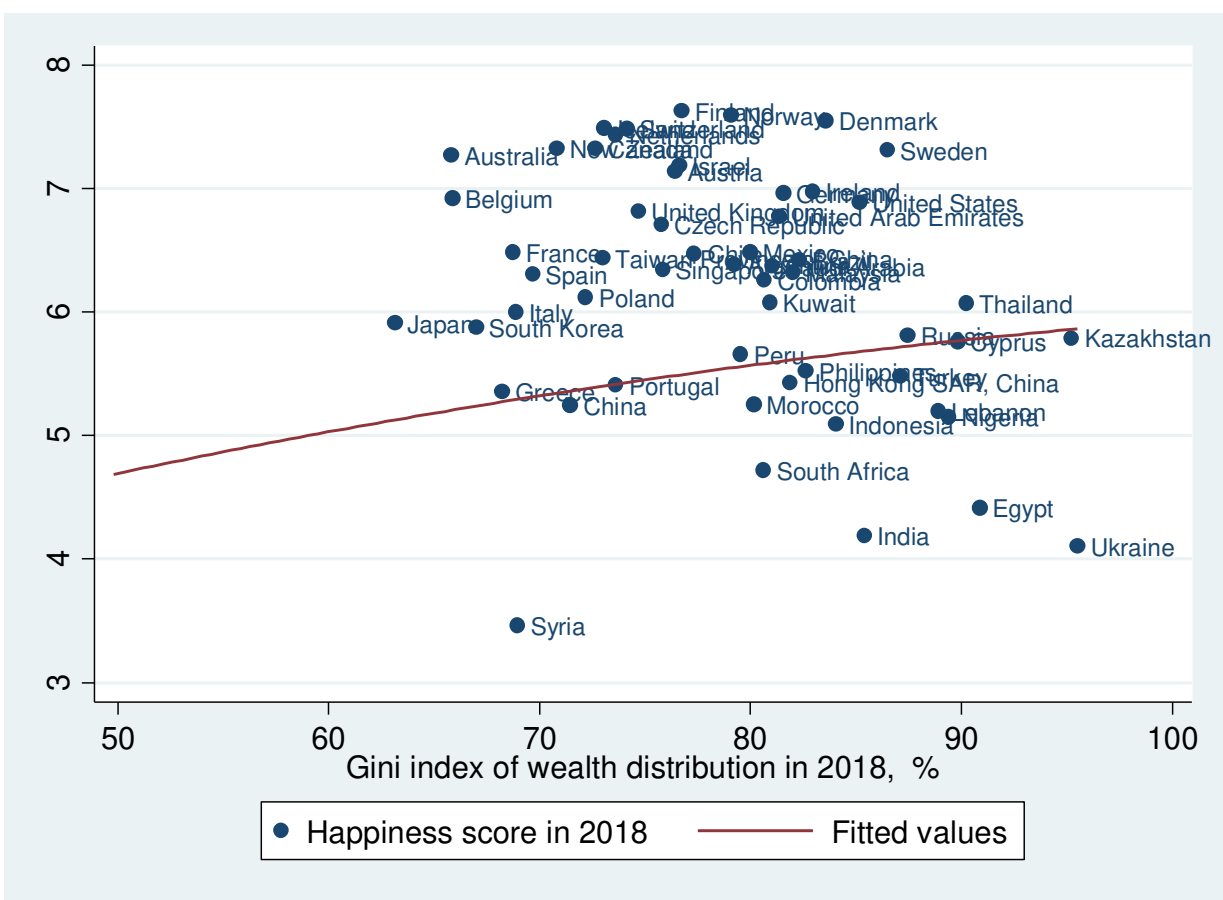

Source: GWR; World Happiness Database; WDI; Forbes billionaires’ list.

Figure 12: Income and wealth inequalities, Gini coefficients in 2000-18, percentage terms

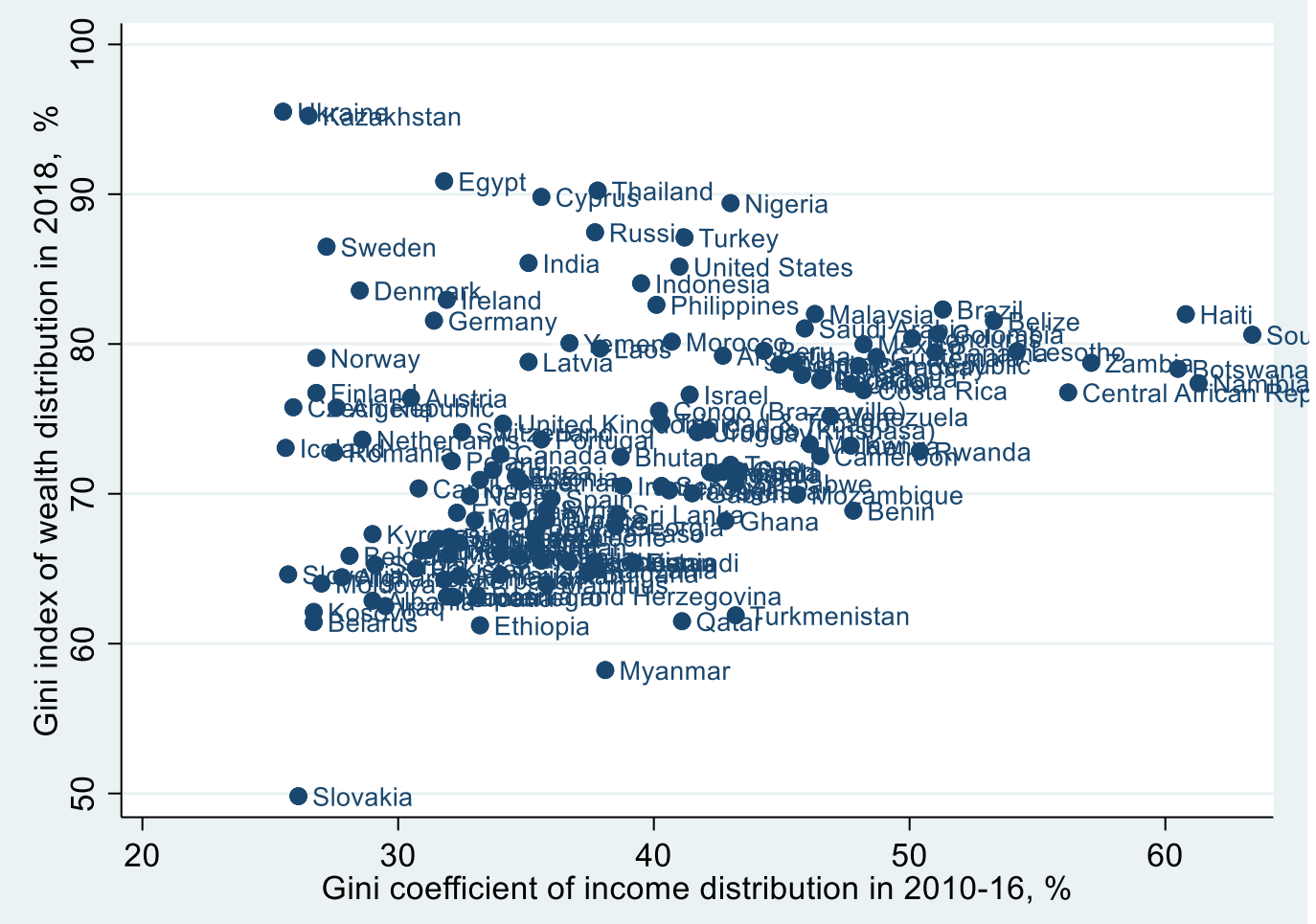


Figure 13: Wealth of billionaires as a percentage of GDP and Gini index of wealth distribution, in percentage terms, in 2018

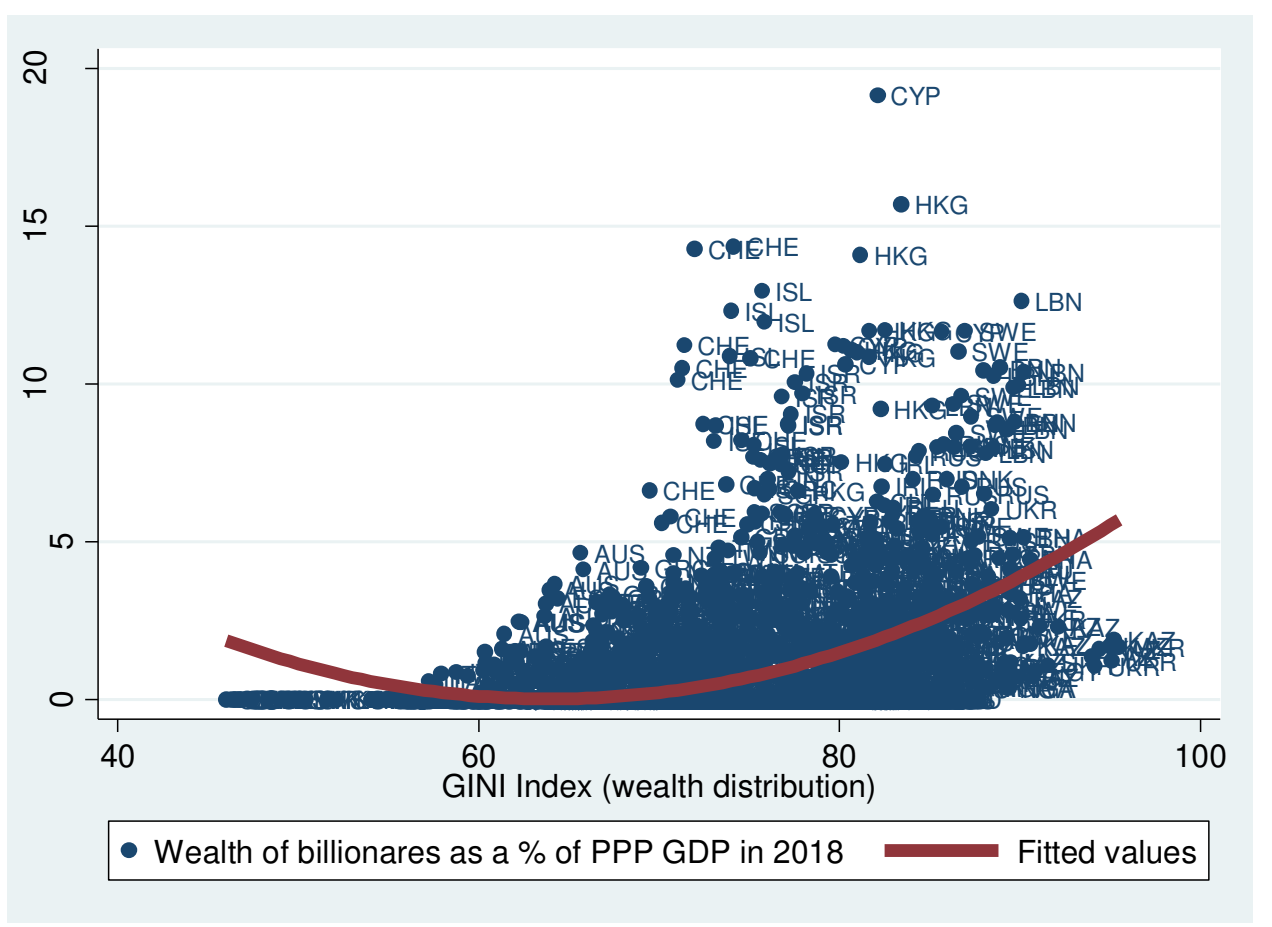

Figure 14: Gini coefficient of income distribution and ratio of billionaire wealth to PPP GDP, percentage terms

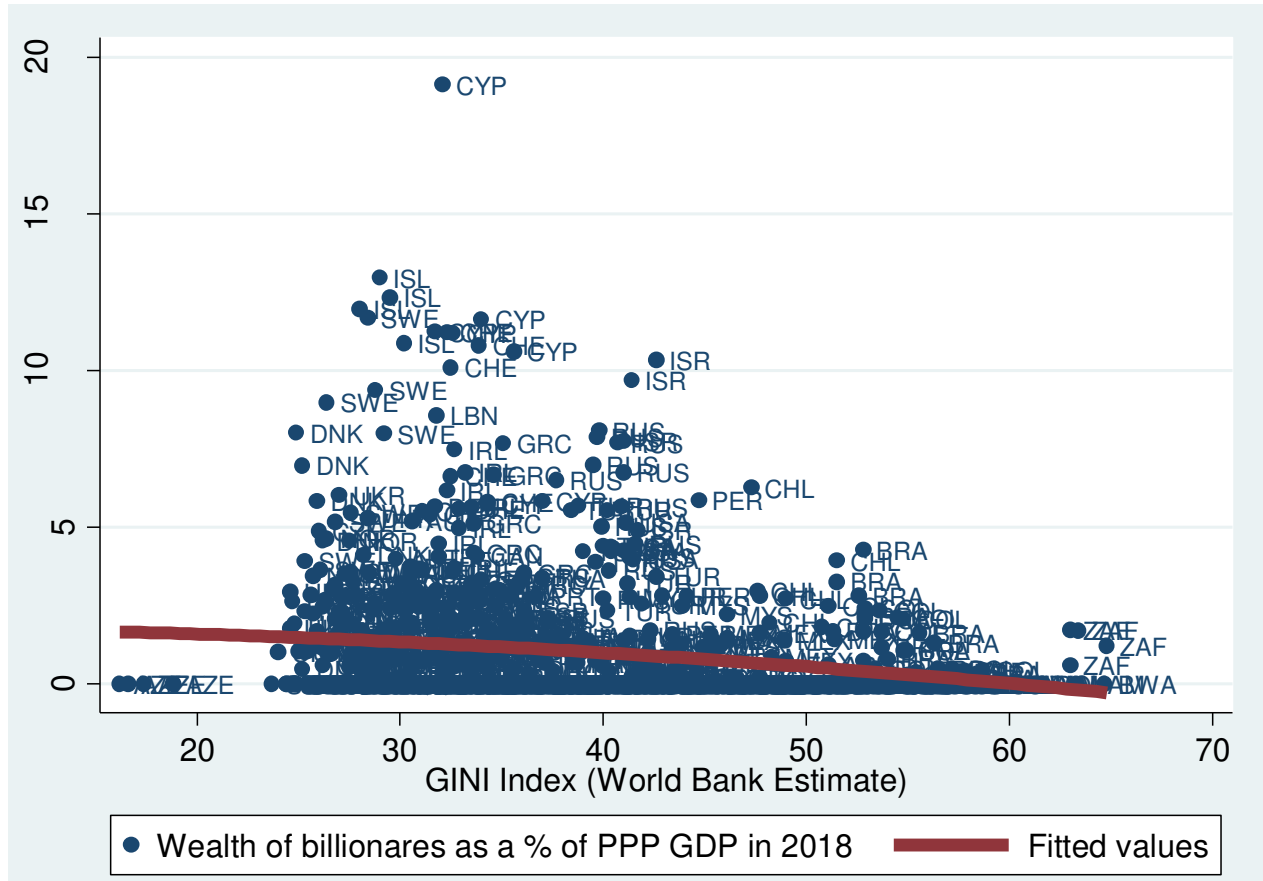

Source: WDI; GWR. 
There are at least two different types of income inequality, presented in the schema below: the same Gini coefficients of income distribution can result from the concentration of inequalities at the high end or the low end of the income pyramid. The graphical interpretation of the Gini coefficient is the ratio of the area between the line of complete equality and the standard Lorenz curve to the area of the shaded triangle.

In the first chart, the $\mathrm{ABC}$ triangle has about the same area as the 'Lorenz curve-complete equality' area - and the same Gini coefficient - but inequality in concentrated at the top end. So the $90 \%$ of the population at the poorer end of the income distribution are totally equal in their income among themselves, but only account for $50 \%$ of total income, whereas the richest $10 \%$ have the other $50 \%$ of total income; the per-capita income of the rich is exactly nine times higher than the per capita income of the poor. ${ }^{8}$

In the second chart, the $\mathrm{ABD}$ triangle also has about the same area as the 'Lorenz curve-complete equality' area - and the same Gini coefficient - but inequality exists because the lower half of society has no income at all, and the other half has all the income.

The data seem to suggest that the first type of income distribution - ' $90 \%$ poor and equal, $10 \%$ rich' - is better for happiness than the second type.

$8(50: 10) /(50: 90)=9$ 


\section{Schema: Two types of inequality with the same Gini coefficient}
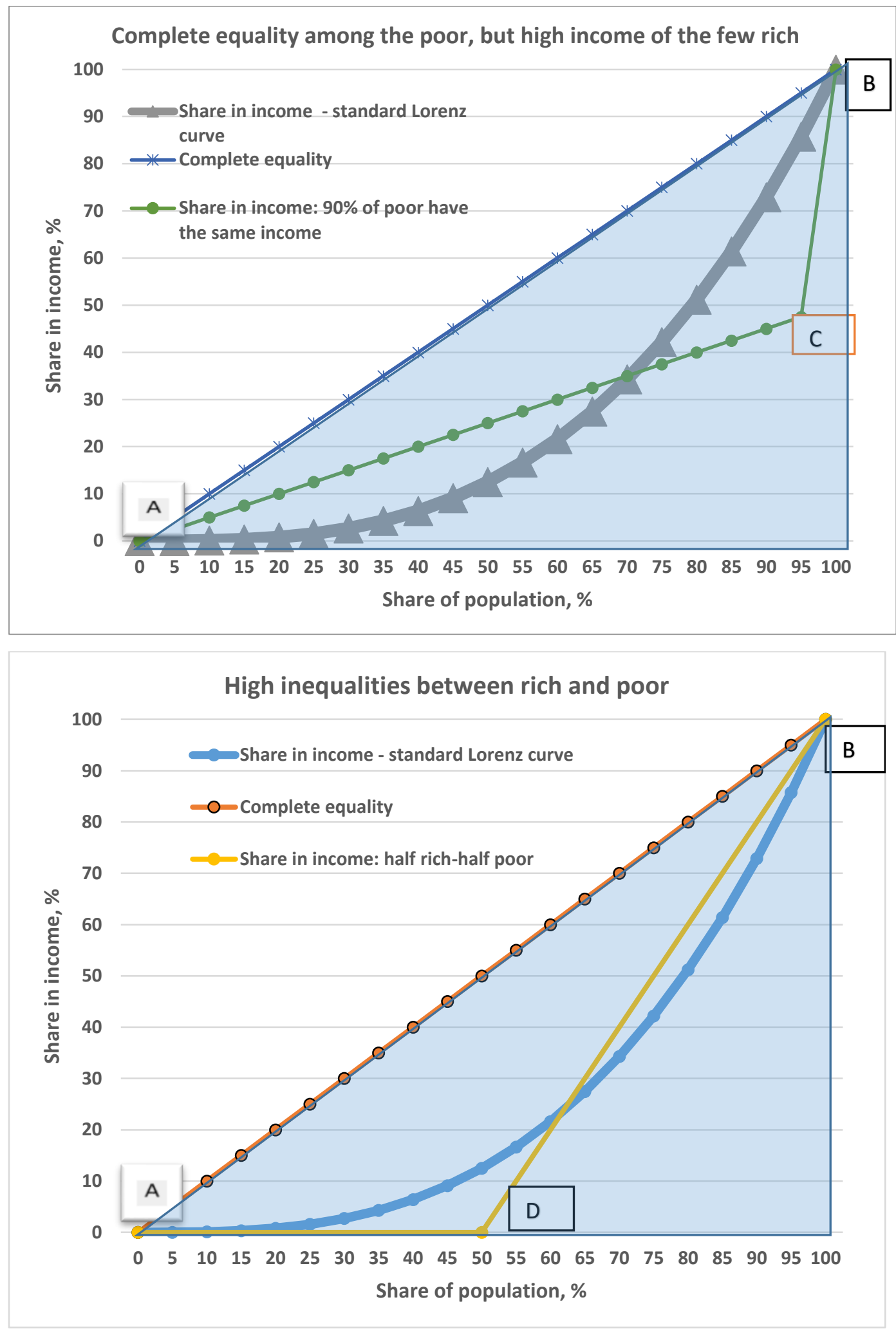
An explanation of the 'inequality-happiness' relationship in terms of statics (space - geography) and dynamics (time - history) could be the 'big fish in a small pond' effect. This is a model developed by Marsh and Parker (1984) to explain why good students prefer to stay in a class in which they are above the average level, rather than be in a more challenging learning environment where they are below the average level. This effect can be used to explain one of the paradoxes of happiness: Strong growth is usually accompanied by growing income inequalities (Popov, 2018a, fig. 10), so rapid growth is often associated with low happiness scores. A paper by Brockmann, Delhey, Welzel, and Hao (2008) refers to the concept of "frustrated achievers" and explains the decline in happiness scores in China through the deterioration of relative incomes for the majority of the population due to rises in income inequality.

But there is a different relationship with regards to levels and change, stocks and flows, and space and time dimensions: with low levels of inequality people feel unhappy - the dream of the 'big fish in a small pond' is out of reach - but the transition to higher levels of inequality, when the relative position of the majority deteriorates in relation to the average, makes people even more unhappy temporarily, during the transition. When transition to a higher level of inequality is over, people - maybe new generations - start to feel happier.

The other explanation could be a different relationship between happiness and inequality in rich and poor countries. The dependence of happiness on income is characterised by a rising but concave curve (fig. 14) that reaches its maximum at a level of income of about $\$ 75,000$ (the level of very rich Norway and Kuwait) and which increases only marginally after the income level of about $\$ 30,000$ (the level of the poorest OECD members - Greece, Chile, and Estonia). Whereas happiness index scores rise from 3 to 6 with a rise of PPP GDP per capita from less than $\$ 1,000$ to $\$ 30,000$, they only increase from 6 to 7 when per-capita income rises from $\$ 30,000$ to $\$ 75,000$ (fig. 15). 
Figure 15: Happiness index (Word Happiness Report and World Database on Happiness), 0-to-10 scale, and PPP GDP per capita in 2018, Dollars

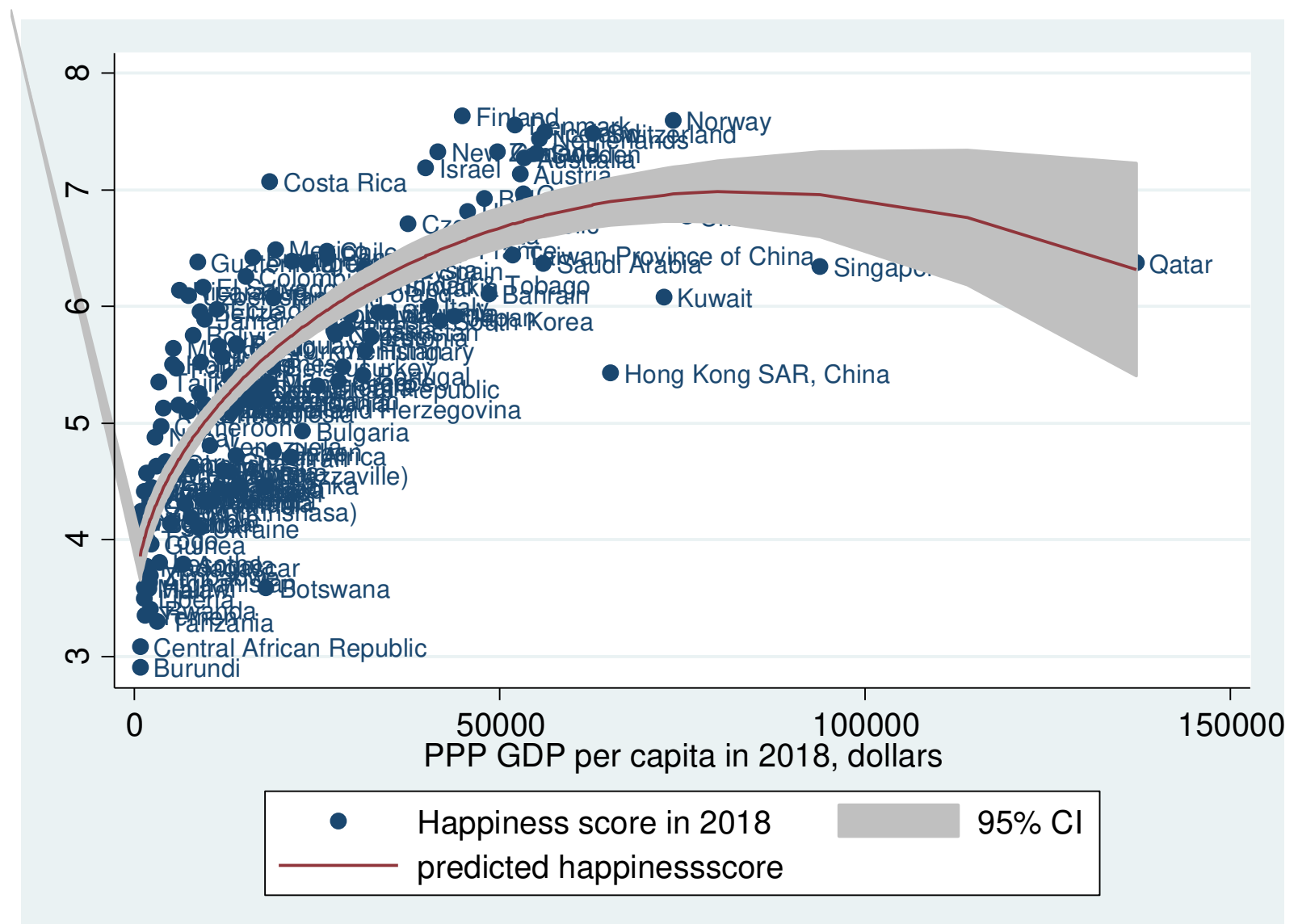

Source: World Database on Happiness, 2019; WDI.

It may well be that in rich countries, the 'money can't buy happiness' story is more true than in poor countries; i.e., a marginal increase in happiness due to a unit increase in income in rich countries is lower than in poor countries.

First, for rich people, non-income determinants of happiness probably play a larger role, so the negative effects of inequality are not counterweighted by higher incomes. Second, in rich countries, people derive pleasure from being better off than most of the world population - i.e., their 'American dream' has been achieved already - so inequality in their own country is less important and has only negative consequences. 
This paper uses the databases from the Forbes billionaires list and the Global Wealth Report (GWR), as well as from the World Happiness Report and the World Database on Happiness. I use the data to examine the relationship between income inequality, and happiness for nearly 20 years (2000-18) for over 200 countries.

It turns out that inequality grows together with happiness in relatively poor countries, but harms happiness in rich countries. On the other hand, inequality of wealth distribution - wealth is a stock variable whereas income is a flow - is positively linked to happiness in all countries. Wealth distribution at the very top of the pyramid - billionaire and millionaire wealth as a proportion of GDP - is one of the most important determinants of happiness index scores in all countries.

The stylised fact is that there are two 'typical' statistical portraits of a happy country. One is of a country with relatively high income compared to the world average, a low level of income inequality, but high wealth inequality and especially high wealth inequality at the very top millionaire and billionaire intensity. This is very much the image of a Scandinavian country - high income compared to the rest of the world, low income inequality within the country, but pretty high wealth inequality and billionaire intensity within the country. The other type of happy country has lower levels of income, but high income and wealth inequalities, especially at the top of the wealth pyramid. This is the Latin American and African model; e.g., Honduras, Bolivia, Ecuador, Costa Rica, South Africa, and Zimbabwe.

\section{Data}

Income. Data on income are from the World Development Indicators database - purchasing power parity (PPP) GDP per capita.

Happiness. Data on happiness come from the World Happiness Report, as well as from the World Database on Happiness. This represents individuals' self-perception of how happy they are. The scale is from 0 to 10 , and the estimates are derived from the Gallup World Poll, the World Values Survey, and other sources. 
Income and wealth inequalities. Income inequalities data are from the World Development Indicators database (WDI) and derived from national household surveys of income and consumption in various countries. Wealth inequalities are computed through extrapolation: first, regressions between the components of personal financial and non-financial wealth and its determinants (real consumption; population density; market capitalisation rate; public pensions as a percentage of GDP; domestic credits available to private sector; and Gini coefficient of income distribution) are computed for about 40 countries for which these data are available, then an extrapolation is made for countries that do not have estimates of these components of personal wealth (Davies, Sandström, Shorrocks, and Wolff, 2007).

Wealth of high net worth individuals (HNWI) - billionaires and millionaires. Sample surveys tend to omit HNWIs, so income and wealth distribution at the very top of the pyramid is very much underestimated. That is why this paper uses the Forbes list of billionaires, which reports the wealth of all billionaires in the world since 1996 - see Popov (2018a) for details - and the Credit Suisse Global Wealth Report, which makes a number of adjustments to the Forbes data on billionaires (GWD, 2018, pp. 110-113) and estimates the number and wealth of multi-millionaires, millionaires, and other HNWIs. ${ }^{9}$

\footnotetext{
${ }^{9}$ This is how the estimation procedure is explained in the GWR: "We exploit the fact that the top tail of wealth distribution is usually well approximated by the Pareto distribution, which produces a straight-line graph when the logarithm of the number of persons above wealth level w is plotted against the logarithm of w. Our data yield a close fit to the Pareto distribution in the wealth range from USD 250,000 to USD 5 million. Above USD 5 million the relationship begins to break down, and the correspondence weakens further above USD 50 million, as expected given the limitations of the data sources. However, it still seems reasonable to use a fitted Pareto line to estimate the number of individuals in the highest echelons of the wealth distribution. To determine the precise features of the top wealth tail, we rely heavily on the rich list data provided by Forbes and other sources. We make particular use of the number of billionaires reported by Forbes, since the data are available for many years and are broadly comparable across countries. We recognize that rich list data have limitations. The valuations of individual wealth holdings are dominated by financial assets, especially equity holdings in public companies traded in international markets. For practical reasons, less attention is given to nonfinancial assets apart from major real estate holdings and trophy assets, such as expensive yachts. Even less is known - and hence recorded - about personal debts. Some people cooperate enthusiastically with those compiling the lists; others jealously guard their privacy. There are also different country listings for nationals and residents, which is especially evident for India, for instance. The true legal ownership within families - as opposed to nominal ownership or control - adds further complications. Assigning the wealth recorded for Bill Gates, for example, to all family members might well result in several billionaire holdings, so the number of billionaires would increase in this instance. In other cases, reassigning the family wealth would reduce all the individual holdings below the billionaire threshold. For all these reasons, rich list data should be treated with caution. At the same time, the broad patterns and trends are informative, and they provide the best available source of information at the apex of global wealth distribution" (GWR, 2018, p. 111).
} 
Forbes data show a higher ratio of billionaire wealth to GDP than the GWR data. For instance, for Hong Kong, the comparison is $58 \%$ and $30 \%$ respectively. But overall, these two estimates are strongly correlated (fig. 16).

Figure 16: Billionaire intensity in percentage terms of PPP GDP according to the Forbes list and according to the Global Wealth Report

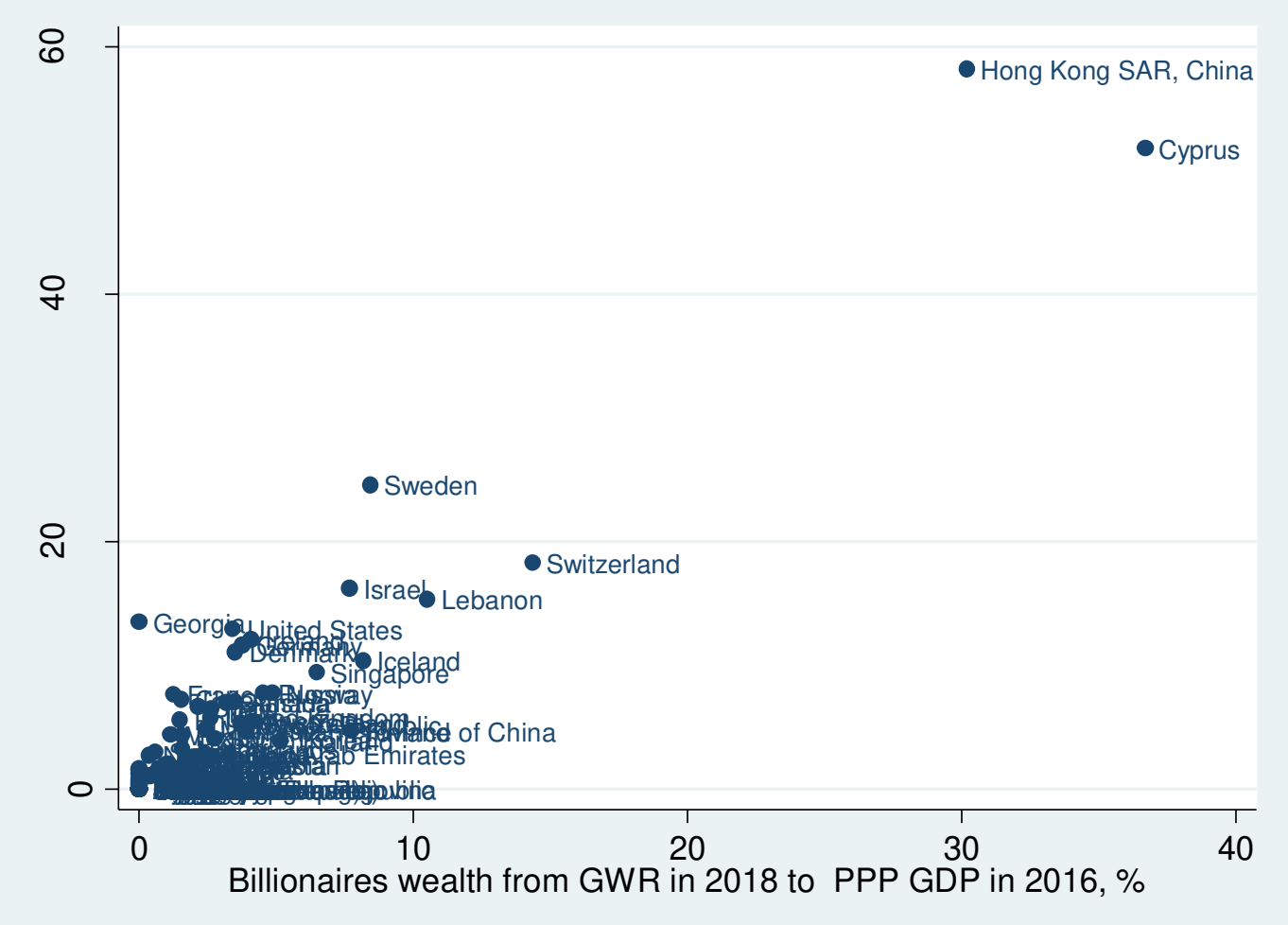




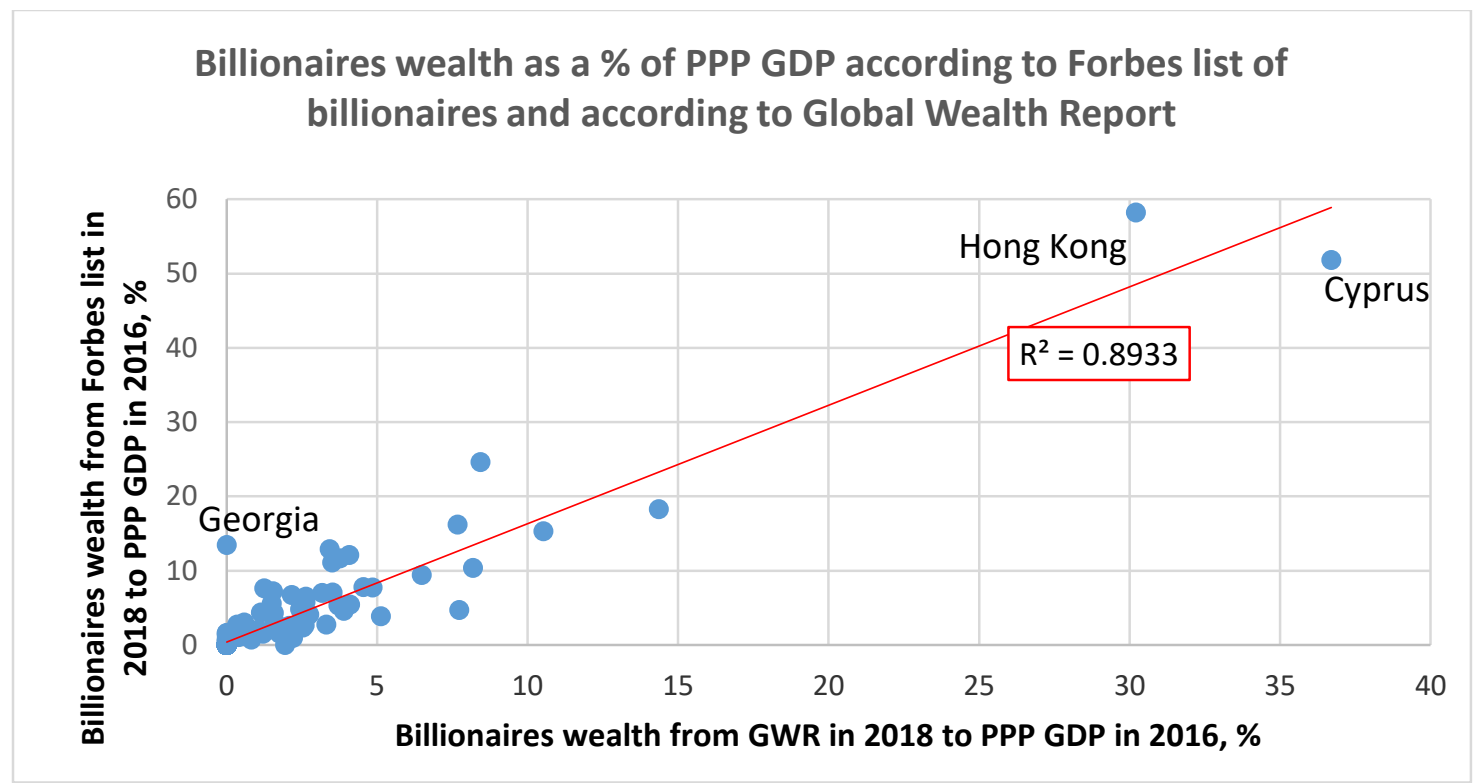

Source: GWR; Forbes.

As figure 17 suggests, the ratio of millionaire wealth to GDP is correlated with the ratio of billionaire wealth to GDP. However, data on the wealth of millionaires have the advantage of including more countries. In 2018, there were only 24 countries, out of over 150, for which data were available that did not have a single millionaire; in contrast the number of countries without billionaires was nearly 100 out of over 150 .

Suicide and murder rates. These data come from World Health Organization statistics on causes of death. ${ }^{10}$ Murder rates statistics is also available from the UNODC (United Nations Office on Drugs and Crime), which collects statistics mostly from WHO but from other sources as well.

\footnotetext{
${ }^{10}$ External causes of death include murders, suicides, accidents, and 'unidentified'.
} 
Figure 17: Millionaire and billionaire intensity of PPP GDP according to the Global Wealth

\section{Report, percentage terms}
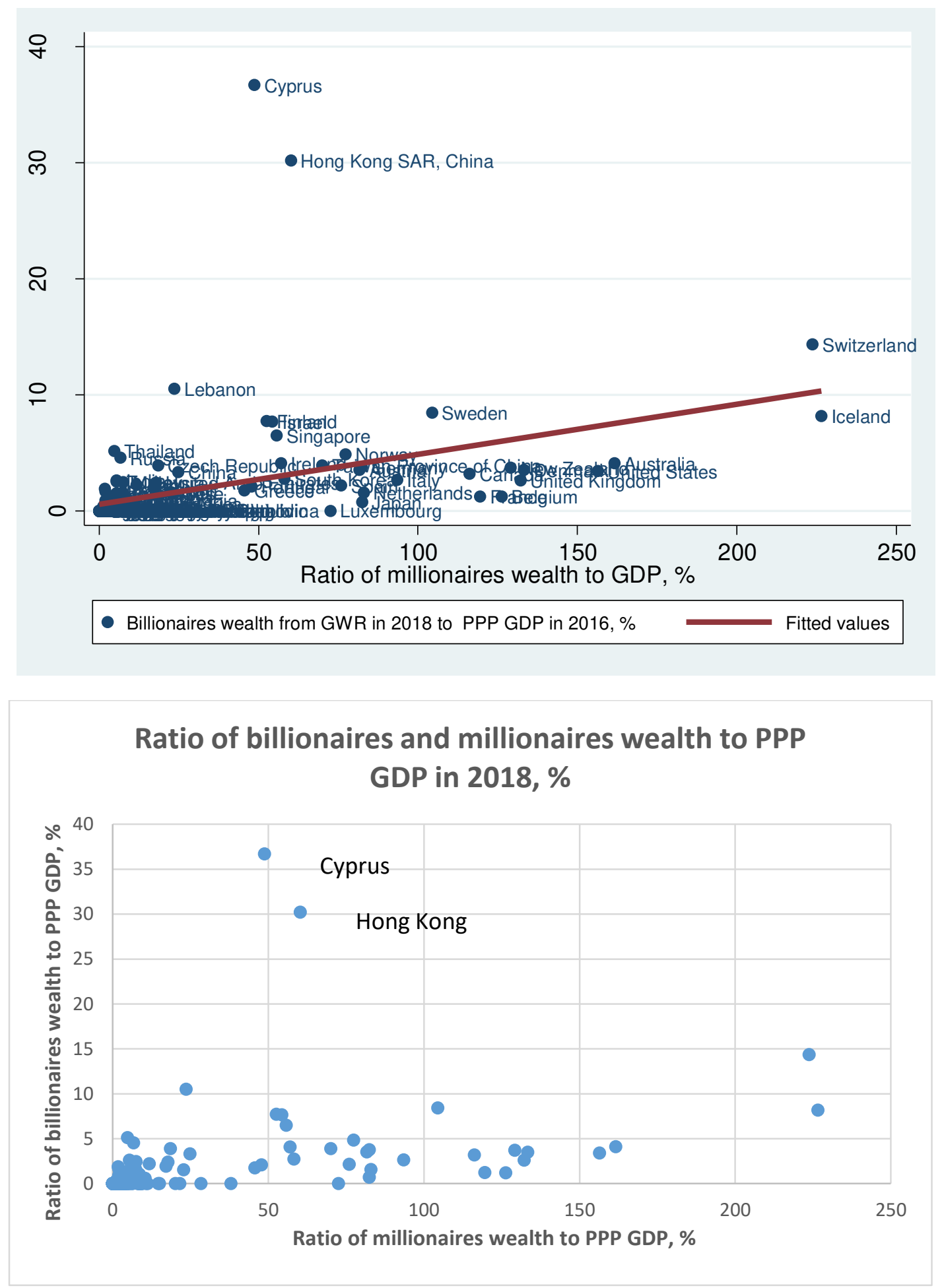

Source: Global Wealth Report. 


\section{Results: More billionaires - less inequality, fewer murders, and more happiness}

To begin with, it is important to remember that billionaire intensity is negatively related to income inequalities - the lower the level of inequality, the more billionaires per unit of GDP the country has, even controlling for the level of income and for random effects. ${ }^{11}$ This relationship is counterintuitive and suggests that inequalities at the very top are more pronounced than inequalities among other income groups.

Table 1 reports the results of regressions of happiness indices on various determinants without controls for fixed and random effects.

Models 1.1-1.6 link happiness indices to income and wealth inequalities and to billionaire and millionaire intensity - with and without controls for per capita income - with similar results: wealth inequality and billionaire and millionaire intensity have positive effect on happiness, whereas income inequality affects happiness negatively. Models 1.1-1.2 are based on cross-section data from about 150 countries; models 1.3-1.6 are based on panel data. In models 1.3-1.6 (panel data) coefficients become insignificant, if controls for fixed effects or random effects are introduced, which probably suggests non-linearity, so an interaction term - per capita income multiplied by Gini coefficient of income distribution - is introduced in the next model (1.7).

\footnotetext{
${ }^{11}$ Billionare'sIntensity $=2.5 * * *-0,04$ GINIincome $* * * *$

Robust estimate, $\mathrm{R}^{2}=0.03, \mathrm{~N}=1031$ (over 200 countries and 18 years, but some observations are missing).

Billionare'sIntensity $=1.9 * * *-1.7 \mathrm{e}^{-07}$ Ycap $-0,03$ GINIincome $* *$

Random effect regression, $\mathrm{R}^{2}$ (between) $=0.05, \mathrm{~N}=1031$ (over 200 countries and 18 years, but some observations are missing).
}

The following notations are used: *,**,*** denotes significance at 10, 5 and $1 \%$ level respectively. 
Table 1: Regression results of happiness indices on various determinants. Cross country and panel data without control for random and fixed effects (T-statistics add $z$ - statistics in brackets)

\section{Dependent variable - Happiness}

\begin{tabular}{|c|c|c|c|c|c|c|c|}
\hline $\begin{array}{l}\text { Model, parameters, N/ } \\
\text { Variables }\end{array}$ & $\begin{array}{l}1.1, \text { Cross- } \\
\text { country, } \\
\mathrm{N}=139\end{array}$ & $\begin{array}{l}1.2, \text { Cross- } \\
\text { country, } \\
\mathrm{N}=151\end{array}$ & \begin{tabular}{|l}
1.3 \\
Panel, \\
$\mathrm{N}=1967$
\end{tabular} & $\begin{array}{l}\begin{array}{l}1.4, \\
\text { Panel, } \\
\mathrm{N}=1967\end{array}\end{array}$ & $\begin{array}{l}\begin{array}{l}1.5, \\
\text { Panel, } \\
\mathrm{N}=1967\end{array}\end{array}$ & $\begin{array}{l}1.6, \\
\text { Panel, } \\
\mathrm{N}=760\end{array}$ & $\begin{array}{l}1.7, \\
\text { Panel, } \\
\mathrm{N}=760\end{array}$ \\
\hline $\begin{array}{l}\text { PPP GDP per capita, \$, } \\
\text { Ycap }\end{array}$ & & $\begin{array}{l}.00002 * * * \\
(5.2)\end{array}$ & & $\begin{array}{l}3.8 \mathrm{e}^{-06} \\
(1.22)\end{array}$ & $\begin{array}{l}3.6 \mathrm{e}^{-06} \\
(1.3)\end{array}$ & $\begin{array}{l}.00005 \\
* * * \\
(14.8)\end{array}$ & $\begin{array}{l}.0001 * \\
* * \\
(10.2)\end{array}$ \\
\hline $\begin{array}{l}\text { Gini coefficient of income } \\
\text { distribution, } \% \text {, } \\
\text { GINIincome }\end{array}$ & $\begin{array}{l}-.02 * * \\
(1.9)\end{array}$ & & & & & $\begin{array}{l}.04 * * * \\
(9.0)\end{array}$ & $\begin{array}{l}.08 * * * \\
(10.6)\end{array}$ \\
\hline $\begin{array}{l}\text { Gini coefficient of wealth } \\
\text { distribution, } \\
\text { GINIwealth }\end{array}$ & $\begin{array}{l}.03^{* *} \\
(2.4)\end{array}$ & $\begin{array}{l}.02 * * \\
(2.0)\end{array}$ & & & & $\begin{array}{l}0.02 * * \\
* \\
(4.3)\end{array}$ & $\begin{array}{l}.01 * * * \\
(3.6)\end{array}$ \\
\hline $\begin{array}{l}\text { Billionaires' wealth to PPP } \\
\text { GDP ratio, \% } \\
\text { Billionaires'Intensity }\end{array}$ & & & $\begin{array}{l}0.13^{* * * *} \\
(5.7)\end{array}$ & $\begin{array}{l}0.12 * * * \\
(5.2)\end{array}$ & $\begin{array}{l}0.03 * * * \\
(9.6)\end{array}$ & $\begin{array}{l}0.03 * * \\
(2.1)\end{array}$ & \\
\hline $\begin{array}{l}\text { Millionaires' wealth to } \\
\text { PPP GDP ratio, \% } \\
\text { Millionaires'Intensity }\end{array}$ & $\begin{array}{l}.01 * * * \\
(8.56)\end{array}$ & $\begin{array}{l}.008^{* * * *} \\
(4.8)\end{array}$ & & & & & $\begin{array}{l}.06^{* * *} \\
(3.9)\end{array}$ \\
\hline $\begin{array}{l}\text { Interaction term } \\
(\text { Ycap } * \text { GINIincome })\end{array}$ & & & & & & & $\begin{array}{l}-2.6^{\mathrm{e}-06} \\
* * * \\
(-6.6)\end{array}$ \\
\hline Constant & $\begin{array}{l}3.9^{* * *} \\
(5.6)\end{array}$ & $\begin{array}{l}3.6^{* * *} \\
(6.8)\end{array}$ & $\begin{array}{l}5.4 * * * \\
(162.9)\end{array}$ & $\begin{array}{l}5.4^{* * *} \\
(91.9)\end{array}$ & $\begin{array}{l}3.2 * * * \\
(13.6)\end{array}$ & $\begin{array}{l}2.2 * * * \\
(7.1)\end{array}$ & $\begin{array}{l}1.3^{* * *} \\
(4.0)\end{array}$ \\
\hline $\mathrm{R}^{2}, \%$ & 44 & 58 & 9 & 12 & 8 & 45 & 48 \\
\hline
\end{tabular}

$*, * *, * * *$ - denotes significance at 10,5 and $1 \%$ respectively.

Model 1.7 is a specification with the threshold of per-capita income. The resulting equation has the following form: 
Happiness $=1.3^{* * *}+0.0001$ Ycap $* * *+0.01$ GINIwealth $* * *+0.06$ Millionaires'Intensity $* * *+$ $+1.7 \mathrm{e}^{-06}$ GINIincome $* * *\left(30700-\right.$ Ycap $\left.^{* * * *}\right)$

This implies that wealth inequality, both in general and at the top of the wealth pyramid ('millionaire intensity'), has a positive impact on happiness, whereas income inequality has a positive impact only in countries with per capita income above $\$ 30,700$.

Table 2 reports the results of regressions using panel data and controlling for random and fixed effects. Better results are obtained by controlling for random effects; variation within the groups 19 years for the same country - is not enough in most cases to receive meaningful results. But regressions with fixed-effects controls are reported as well, for consistency.

Model 2.1 shows a significant and positive dependence of happiness indices on per-capita income and income inequalities, but once wealth inequalities and billionaire intensity variables are introduced into the right hand side, coefficients become insignificant.

Model 2.2 suggests a non-linear relationship:

Happiness $=3.7^{* * *}+0.00009$ Ycap $^{* * *}+1.6 \mathrm{e}^{-06}$ GINIincome $^{* * *}\left(25000-\right.$ Ycap $\left.^{* * *}\right)$

In countries with per-capita income (PPP GDP per capita) higher than roughly US\$ 25,000 for a particular period, income inequalities have a negative impact on happiness, but in poorer countries the relationship is positive.

Model 2.3 shows the same non-linear relationship with a similar threshold of per-capita income $(\$ 22,100+388 *$ Billionaires' intensity). The interesting twist here is that the higher the level of billionaire intensity, the higher the threshold separating poor and rich countries with regards to the sensitivity of their happiness self-evaluation to income inequalities. In rich countries, income inequalities normally have a negative impact on happiness, but the higher the level of billionaire intensity, the smaller this negative impact is: 
Table 2: Regression results of happiness indices on various determinants. Panel data with controls for random and fixed effects ( $T$-statistics add $z$ - statistics in brackets)

Dependent variable - Happiness

\begin{tabular}{|c|c|c|c|c|c|c|c|}
\hline $\begin{array}{l}\text { Model, parameters, N / } \\
\text { Variables }\end{array}$ & $\begin{array}{l}\text { 2.1, Panel, } \\
\text { random } \\
\text { effects, } \\
\mathrm{N}=760\end{array}$ & $\begin{array}{l}2.2 \text {, Panel, } \\
\text { random } \\
\text { effects, } \\
\mathrm{N}=760\end{array}$ & $\begin{array}{l}\text { 2.3, Panel, } \\
\text { random } \\
\text { effects, } \\
\mathrm{N}=760\end{array}$ & $\begin{array}{l}\text { 2.4, Panel, } \\
\text { fixed } \\
\text { effects, } \\
\mathrm{N}=760\end{array}$ & $\begin{array}{l}2.5 \\
\text { Panel, } \\
\mathrm{N}=658\end{array}$ & $\begin{array}{l}\text { 2.6, Panel, } \\
\text { random } \\
\text { effects, } \\
\mathrm{N}=658\end{array}$ & $\begin{array}{l}\text { 2.7, Panel, } \\
\text { fixed } \\
\text { effects, } \\
\mathrm{N}=658\end{array}$ \\
\hline PPP GDP per capita, $\$$, Ycap & $\begin{array}{l}.00003 * * * \\
(9.4)\end{array}$ & $\begin{array}{l}.00009 * * * \\
(5.6)\end{array}$ & $\begin{array}{l}.00009 * * * \\
(5.7)\end{array}$ & $\begin{array}{l}.00007 * * * \\
(3.9)\end{array}$ & $\begin{array}{l}.00005 \\
* * * \\
(14.9)\end{array}$ & $\begin{array}{l}.00003 * * * \\
(8.2)\end{array}$ & $\begin{array}{l}.00004 * * * \\
(2.8)\end{array}$ \\
\hline $\begin{array}{l}\text { Gini coefficient of income } \\
\text { distribution, \%, GINIincome }\end{array}$ & $\begin{array}{l}.02 * * * \\
(3.2)\end{array}$ & $\begin{array}{l}.04 * * * \\
(4.6)\end{array}$ & $\begin{array}{l}.04 * * * \\
(4.6)\end{array}$ & $\begin{array}{l}.02 * * * \\
(2.7)\end{array}$ & $\begin{array}{l}.03 * * * \\
(4.7)\end{array}$ & & \\
\hline $\begin{array}{l}\text { Gini coefficient of wealth } \\
\text { distribution, } \%, \text { GINIwealth }\end{array}$ & & & & & $\begin{array}{l}.02 * * * \\
(4.2)\end{array}$ & & \\
\hline $\begin{array}{llr}\text { Billionaires' } & \text { wealth to } & \text { PPP } \\
\text { GDP } & \text { ratio, } & \% \text {, } \\
\text { Billionaires'Intensity } & \end{array}$ & & & & & $\begin{array}{l}.03 * * \\
(2.4)\end{array}$ & & \\
\hline $\begin{array}{l}\text { Murder rate (per 100,000 } \\
\text { inhabitants), MURDERrate }\end{array}$ & & & & & $\begin{array}{l}.18 * * * \\
(5.4)\end{array}$ & $\begin{array}{l}-.07 * * * \\
(-5.6)\end{array}$ & $\begin{array}{l}-.07 * * * \\
(-5.4)\end{array}$ \\
\hline $\begin{array}{l}\text { Interaction term } \\
(\text { Ycap } * \text { GINIincome })\end{array}$ & & $\begin{array}{l}-1.6 \mathrm{e}^{-06} \\
* * * \\
(3.5)\end{array}$ & $\begin{array}{l}-1.7 \mathrm{e}^{-06} \\
* * * \\
(3.6)\end{array}$ & $\begin{array}{l}-1.9 \mathrm{e}^{-06} \\
* * * \\
(3.8)\end{array}$ & & & $\begin{array}{l}-1.1 \mathrm{e}^{-06 * *} \\
(2.4)\end{array}$ \\
\hline $\begin{array}{lr}\text { Interaction } & \text { term } \\
\text { (GINIincome } & * \\
\text { *Billionaires'Intensity) } & \end{array}$ & & & $\begin{array}{l}.0007 \\
(1.6)\end{array}$ & $\begin{array}{l}.0005 \\
(1.2)\end{array}$ & & & \\
\hline $\begin{array}{lr}\text { Interaction } & \text { term } \\
\text { (GINIincome } & * \\
\text { MURDERrate }) & \end{array}$ & & & & & & $\begin{array}{l}.002 * * * \\
(6.2)\end{array}$ & $\begin{array}{l}.001 * * * \\
(5.2)\end{array}$ \\
\hline Constant & $\begin{array}{l}4.2 * * * \\
(14.9)\end{array}$ & $\begin{array}{l}3.7 * * * \\
(11.7)\end{array}$ & $\begin{array}{l}3.7 * * * \\
(11.7)\end{array}$ & $\begin{array}{l}5.0 * * * \\
(13.8)\end{array}$ & $\begin{array}{l}2.7 * * * \\
(8.8)\end{array}$ & $\begin{array}{l}5.2 * * * \\
(8.2)\end{array}$ & $\begin{array}{l}6.1 * * * \\
(52.8)\end{array}$ \\
\hline $\mathrm{R}^{2}, \%$ & 41 & 42 & 43 & 29 & 47 & 41 & 17 \\
\hline
\end{tabular}

$*, * *, * * *$ - denotes significance at 10,5 and $1 \%$ respectively. 
Happiness $=3.7^{* * *}+0.00008$ Ycap $^{* * *}+1.7 \mathrm{e}^{-06}$ GINIincome $^{* * *}(22100-$ Ycap + $+388^{*}$ BillionaireIntensity $\left.* * *\right)$

Model 2.4 shows the same relationship as model 2.3 (random effects), but with controls for fixedeffects:

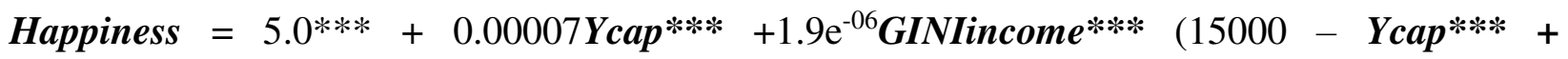
312BillionaireIntensity)

This confirms the robustness of the estimates: the positive effect of income inequalities on happiness for poor countries and the positive effect of billionaire intensity on happiness for all countries is captured in space - cross-country comparisons, i.e., controlling for random effects, as well as in time - time series for a particular country, i.e., controlling for fixed effects. The only difference is the lower threshold: $\$ 15,000$ compared to $\$ 22,000$.

In model 2.5 - panel data without controls for fixed effects and non-linearity - happiness indices are positively and significantly correlated to per-capita income, income inequality, wealth inequality, billionaire intensity, and murder rates. The interpretation could be that inequality at all levels has a stronger positive impact on happiness - a positive impact that outweighs the negative impact of a higher murder rate.

In model 2.6, an additional explanatory variable is introduced: an interaction term between income inequalities and the murder rate. Counterintuitively, the impact of the murder rate on happiness is positive for countries with high income inequalities - those with Gini coefficients of income distribution of over $45 \%$ :

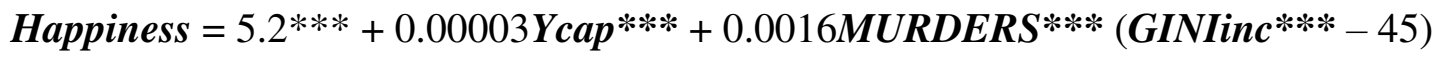

This relationship most likely captures the patterns of poorer countries with high income inequalities. For all rich countries, the Gini coefficient of income distribution is lower than $45 \%$, 
so countries with Gini coefficients of over $45 \%$ are all developing countries. Even high murder rates in these countries do not prevent people from experiencing happiness under high income inequalities, for example, in Latin America and Africa.

Finally, model 2.7 replicates the results with controls for fixed effects:

Happiness $=6.1^{* * *+1.12 \mathrm{e}^{-06} \text { Ycap }^{* * * *}\left(\text { GINIinc }^{* * * * 38}\right)+0.0014 \text { MURDERS }}{ }^{* * *}\left(\right.$ GINIinc $\left.^{* * *}{ }_{-50}\right)$

This result is even stronger than with previous models: In countries with low income inequalities - i.e., Gini coefficients below 38\% - even income growth does not bring happiness, and increase in murders undermines happiness.

In table 3, some results for the determinants of the murder rate and suicide rate are reported. These indicators could be regarded as more objective measures of wellbeing/happiness; i.e., if people are so unhappy with their lives and blame themselves, they commit suicide; if they blame others, they commit murders. Reasons for suicides and especially for murders may be different of course, but it is instructive to see the determinants of both indicators anyway.

Models 3.1-3.2 suggest that the impact of income and wealth inequalities on murder rates is positive, but the impact of wealth inequalities at the top (billionaire intensity) is negative.

Model 3.3 shows that for countries with Gini coefficients of income inequality above 29\% - most countries in the world - billionaire intensity has a negative impact on murder rates:

MURDERrate $=0.3$ IINinc $^{* * *}+0.06$ GINIwealth $* * *+0.08$ Billionaires'Intensity ${ }^{* * *}(29-$ GINIinc) $-8.4^{* *}$

Suicide rates do not necessarily go together with high inequalities. Whereas one might expect that people may feel less happy in countries with, and in times of, high levels of inequality in income and wealth distribution, such that suicide rates in these countries and these periods are higher, in fact, suicide rates do not exhibit any strong correlation with income and wealth distribution. 
Table 3: Regressions of murder rate and suicide rate on determinants

\begin{tabular}{|c|c|c|c|c|c|c|}
\hline & Dependent & variable $-\mathrm{N}$ & URDERrate & Dependen & variable & SUICIDErate \\
\hline $\begin{array}{l}\text { Model, parameters, N/ } \\
\text { Variables }\end{array}$ & $\begin{array}{l}\text { 3.1, Panel, } \\
\mathrm{N}=876\end{array}$ & $\begin{array}{l}3.2, \text { Panel, } \\
\text { random } \\
\text { effects, } \\
\mathrm{N}=876\end{array}$ & $\begin{array}{l}3.3, \text { Panel, } \\
\text { random } \\
\text { effects, } \\
\mathrm{N}=876\end{array}$ & $\begin{array}{l}\text { 3.4, Panel, } \\
\mathrm{N}=197\end{array}$ & $\begin{array}{l}3.5, \\
\text { Panel, } \\
\text { random } \\
\text { effects, } \\
\mathrm{N}=197\end{array}$ & $\begin{array}{l}\text { 3.6, Panel, } \\
\text { fixed effects, } \\
\mathrm{N}=197\end{array}$ \\
\hline PPP GDP per capita, \$, Ycap & $\begin{array}{l}-1.8 \mathrm{e}^{-06 * *} \\
(-2.5)\end{array}$ & & & $\begin{array}{l}-3.5 \mathrm{e}^{-06} \\
* * * \\
(-4.7)\end{array}$ & $\begin{array}{l}-2.2 \mathrm{e}^{-06} \\
(-1.3)\end{array}$ & \\
\hline $\begin{array}{l}\text { Gini coefficient of income } \\
\text { distribution, } \%, \text { GINIincome }\end{array}$ & $\begin{array}{l}.8^{* * * *} \\
(15.4)\end{array}$ & $\begin{array}{l}.3 * * * \\
(5.1)\end{array}$ & $\begin{array}{l}.3^{* * *} \\
(5.3)\end{array}$ & $\begin{array}{l}-.1 * * * \\
(-2.7)\end{array}$ & $\begin{array}{l}.06 \\
(1.1)\end{array}$ & $\begin{array}{l}.22 * * * \\
(2.9)\end{array}$ \\
\hline $\begin{array}{l}\text { Gini coefficient of wealth } \\
\text { distribution, } \% \text {, GINIwealth }\end{array}$ & $\begin{array}{l}.2^{* * *} \\
(5.6)\end{array}$ & & $\begin{array}{l}.06 \\
(1.2)\end{array}$ & & & $\begin{array}{l}-.2 \\
(-1.6)\end{array}$ \\
\hline $\begin{array}{l}\text { Billionaires' wealth to PPP } \\
\text { GDP ratio, } \% \text {, } \\
\text { Billionaires'Intensity }\end{array}$ & $\begin{array}{l}-.9 * * * \\
(-6.5)\end{array}$ & $\begin{array}{l}-.3 * * * \\
(-2.7)\end{array}$ & $\begin{array}{l}2.4 * * * \\
(3.8)\end{array}$ & & & \\
\hline $\begin{array}{l}\text { Interaction term } \\
(\text { Ycap * GINIincome })\end{array}$ & & & & & & \\
\hline $\begin{array}{lr}\text { Interaction } & \text { term } \\
\text { (GINIincome } & * \\
\text { *Billionaires'Intensity) } & \end{array}$ & & & $\begin{array}{l}-.08 * * * \\
(-4.4)\end{array}$ & & & \\
\hline $\begin{array}{lr}\text { Interaction } & \text { term } \\
\text { (GINIincome } & * \\
\text { MURDERrate) } & \end{array}$ & & & & & & \\
\hline Constant & $\begin{array}{l}34.9^{* * *} \\
(9.6)\end{array}$ & $\begin{array}{l}3.5 \\
(1.5)\end{array}$ & $\begin{array}{l}-8.4 * * \\
(-1.9)\end{array}$ & $\begin{array}{l}16.4^{* * * *} \\
(8.3)\end{array}$ & $\begin{array}{l}9.2 * * * \\
(4.3)\end{array}$ & $\begin{array}{l}15.4^{*} \\
(2.0)\end{array}$ \\
\hline $\mathrm{R}^{2}, \%$ & 38 & 37 & 35 & 5 & 0 & 4 \\
\hline
\end{tabular}

$*, * *, * * *$ - denotes significance at 10,5 and $1 \%$ respectively.

The best equations are reported in table 3: there is some indication that income inequalities cause the suicide rate to fall (model 3.4), but once controls for random effects are introduced, the 
relationship totally disappears (model $3.5-\mathrm{R}^{2}=0$, all coefficients are insignificant), whereas in the fixed effects model 3.6, income inequalities have a positive impact on the suicide rate but wealth inequalities have a negative impact on the suicide rate.

\section{Conclusions}

To summarise, income and wealth inequalities do not always cause happiness levels to fall. It is true that inequalities have an array of negative social consequences, well described in the literature - from an increase in crime and mortality to a decline in educational attainment and a proliferation of psychological disorders and obesity (Wilkinson and Pickett, 2010). Besides, inequalities undermine social mobility and lead to the conservation of social stratification: the higher the level of inequality, the higher the probability that one's income will closely resemble that of one's parents - known as the 'Great Gatsby' curve. Hence the social structure, and very often the political structure of society, becomes less flexible as well.

"The frequent claim that inequality promotes accumulation and growth does not get much support from history. On the contrary, great economic inequality has always been correlated with extreme concentration of political power, and that power has always been used to widen the income gaps through rent-seeking and rent-keeping, forces that demonstrably retard economic growth" (Milanovic, Lindert, and Williamson, 2007).

\section{As Joseph Stiglitz explains,}

"widely unequal societies do not function efficiently, and their economies are neither stable, nor sustainable in the long run... When the wealthiest use their political power to benefit excessively the corporations they control, much needed revenues are diverted into the pockets of a few instead of benefiting society at large... That higher inequality is associated with lower growth - controlling for all other relevant factors - have been verified by looking at the range of countries and looking over longer periods of time" (Siglitz, 2012, p. 83, 117). 
Latin American countries, writes Stiglitz, may show a glimpse of the future to other states that are just stepping out on the road leading to growing inequalities.

"The experience of Latin American countries, the region of the world with the highest level of inequality, foreshadows what lies ahead. Many of the countries were mired in civil conflict for decades, suffered high levels of criminality and social instability. Social cohesion simply did not exist" (Stiglitz, 2012, p. 84).

Developing countries with high levels of income inequality are more likely than others to end up in a vicious circle: a bad equilibrium with poor quality institutions, low growth, low levels of social mobility, and high social tensions. It may take a revolution to break this vicious circle and to exit the bad equilibrium (Popov, 2014).

But some inequality is obviously not only tolerated by society, but is also indispensable to obtaining the feeling of happiness. Wealth is increasingly not inherited, but self-made, even in advanced countries (Freund and Oliver, 2016). The most rapid growth in the number of self-made billionaires and in the growth in their wealth is in East Asia, but such figures are also growing in Latin America and Sub-Saharan Africa. ${ }^{12}$ This may be the reason why self-evaluations of happiness are often affected positively by income and wealth inequalities, especially at the top of the distribution pyramid. In particular, there is strong evidence that: (1) income and wealth inequalities in relatively poor countries - with personal incomes below US $\$ 20,000-30,000$ - affect happiness positively; and that (2) the relative wealth of billionaires and millionaires - as a percentage of GDP - contributes to feelings of happiness in poor and rich countries.

This paper contributes to the existing literature by specifying the non-linear impact of inequality on happiness: income inequality raises happiness, rather than lowers it, in relatively poor countries with per-capita income below $\$ 20,000-30,000$, whereas in rich countries lower inequality makes people feel better.

\footnotetext{
12 The Middle East and North Africa is the only region where the share of inherited wealth is growing and the wealth share of company founders is falling.
} 
Inequality of wealth distribution - which is distinct from inequality of income because wealth is a stock variable, whereas income is a flow - is positively linked to happiness in all countries. Furthermore, wealth distribution at the very top of the pyramid - the billionaire and millionaire wealth as a percentage of GDP - is one of the most important determinants of happiness index scores in all countries. Wealth inequality is probably less irritating to people than income inequality because wealth is associated with the past, i.e., it is always inherited or acquired from the past, whereas income concerns the present, and current injustices hurt more than past ones.

Consequently, there are two statistical portraits of a happy country: one has high income per capita compared to the world average, a low level of income inequality, but high wealth inequality and especially high wealth inequality at the very top - millionaire and billionaire intensity. Very much like a typical Scandinavian country. The other type of a happy country has lower levels of income, but high income and wealth inequalities, especially at the top of the wealth pyramid. This is the Latin American and African model; e.g., Honduras, Bolivia, Ecuador, Costa Rica, South Africa, and Zimbabwe. In both cases, wealth inequality at the very top contributes to happiness more than inequality among other income groups. The simplified picture of the happy society is that of $99 \%$ of the population having roughly similar incomes at around the average level for these $99 \%$, but where the remaining $1 \%$ are millionaires and billionaires. 


\section{References}

Alesina, A. and La Ferrara, E. (2001). Preferences for Redistribution in the Land of Opportunities. NBER Working Paper, no. 8267.

Alesina, A., Di Tella, R., MacCulloch, R. (2001). Inequality and Happiness: Are Europeans and Americans Different? NBER Working Paper, no. 8198.

Alesina, A. and Giuliano, P. (2009). Preferences for redistribution. NBER Working Paper no. 14825 .

Brockmann, H., Delhey, J., Welzel, C., and Yuan, H. (2008). The China Puzzle: Falling Happiness in a Rising Economy. Journal of Happiness Studies, 10(4), pp. 387-405.

Chapman, J. (2018). Inequality and Poor Law Policy in Late Victorian England. Retrieved from Http://eh.net/eha/wp-content/uploads/2018/06/Chapman.pdf.

Davies, J. B., Sandström, S., Shorrocks, A., and Wolff , E. N. (2007). Estimating the Level and Distribution of Global Household Wealth. WIDER Research Paper, no. 77. Retrieved from https://www.wider.unu.edu/publication/estimating-level-and-distribution-global-householdwealth.

Easterlin, R. (2016). The science of happiness can trump GDP as a guide for policy. World Economic Forum. Retrieved from https://www.weforum.org/agenda/2016/04/the-science-ofhappinesscan-trump-gdp-as-a-guide-for-policy.

Freund, C. and Oliver, S. (2016). The Origins of the Superrich: The Billionaire Characteristics Database. The Petersen Institute for International Economics, Working Paper no 16-1. Retrieved from https://piie.com/publications/wp/wp16-1.pdf. 
Credit Suisse. (2018). Global Wealth Report; Global Wealth Databook 2018. Retrieved from https://www.credit-suisse.com/corporate/en/research/research-institute/global-wealthreport.html.

Helliwell, J., Layard, R., and Sachs, J. (2018). World Happiness Report 2018. New York: Sustainable Development Solutions Network.

Sundaram, J. K. and Popov, V. (2015). Income Inequalities in Perspective. Development, 58(23), pp. 196-205.

Kuznets, S. (1955). Economic Growth and Income Inequality. American Economic Review, 45, pp. 1-28.

Marsh, H. W. and Parker, J. W. (1984). Determinants of student self-concept: Is it better to be a relatively large fish in a small pond even if you don't learn to swim as well? Journal of Personality and Social Psychology, 47(1), pp. 213-231.

Milanovic, B. (2008). Where in the world are you? Assessing the importance of circumstance and effort in a world of different mean country incomes and (almost) no migration. The World Bank, Working Paper S4493.

Piketty, T., Saez, E., and Zucman, G. (2016). Distributional National Accounts: Methods and Estimates for the United States. NBER Working Paper, no. 22945. Retrieved from https://www.nber.org/papers/w22945.

Popov, V. (2014). Mixed Fortunes: An Economic History of China, Russia and the West. Oxford: Oxford University Press.

Popov, V. (2018a). Paradoxes of happiness: Why do people feel more comfortable with high levels of inequality and high murder rates? DOC Research Institute. Retrieved from https://docresearch.org/2018/06/paradoxes-happiness/. 
Popov, V. (2018b). Why do some countries have more billionaires than others? Explaining variations in the billionaire intensity of GDP. DOC Research Institute. Retrieved from https://pages.nes.ru/vpopov/documents/Billionaires_Web-upload.pdf.

Sachs, J. D. (2018). America's Health Crisis and the Easterlin Paradox. In J. Helliwell, R. Layard, and J. Sachs (Eds.), (2018). World Happiness Report 2018 (Chapter 7, pp. 146-159). New York: Sustainable Development Solutions Network.

Stiglitz, J. (2012). The price of inequality: How today's divided society endangers our future. New York: W.W. Norton \& Co.

UNODC (2019). United Nations Office on Drugs and Crime.

WDI (World Development Indicators) database (2018).

WHO (2018). World Health Organization. Causes of death statistics. Retrieved from Http://apps.who.int/gho/data/node.main.GHECOD?lang=en.

Wilkinson, R., Pickett, K. (2010). The Spirit Level: Why Greater Equality makes Societies Stronger. New York: Bloomsbury Press.

World Database on Happiness (2019). Retrieved from https://worlddatabaseofhappiness.eur.nl/. 